\title{
Osmanlı Kıraat Eğitiminde Tarikler, Meslekler ve Mesleklerin Temel Eserleri`
}

Ahmet Gökdemir

\section{Öz}

Makalede Osmanlı kıraat eğitiminde tarikler, meslekler ve mesleklerin temel kaynakları işlenmektedir. Tarikler başlığında tarik kelimesinin ne anlama geldiği, tariklerin tasnif çeşitleri ile Osmanlı'daki durumlarına değinilmiştir. Meslekler başlığında ise mesleklerin kurucuları ile kaynaklarına yer verilmiş̧ir.

Makalenin yazılış amacı Osmanlı kıraat eğitimindeki tariklerin uygulanış şekilleri ile bu tariklerin Osmanlı'dan önceki uygulamalardan farklı olduğu noktaları ortaya koymaktır. Ayrıca daha önce aynı konuda yazılmış makalelerden farklı olarak mesleklerin kurucularıyla temel kaynaklarını ayrıntılı bir şekilde ele almaktır.

Makalede Osmanlı'da tariklerin uygulanış şekilleri ve isimlendirilmelerinde öncesine göre birtakım farklılıklar olduğu sonucuna ulaşılmıştır. Meslekler ve mesleklerin kaynakları başlı̆̆ında ise makalede adı geçen kaynakların daha ziyade kıraat ilminin tahrirat kısmına yönelik olduğu kanısına varılmıştır.

Anahtar Kelimeler: Osmanl, kıraat, tarik, meslek, tahrirat.

* Bu makale Ahmet Gökdemir'in 2017 tarihinde Yalova Üniversitesi Sosyal Bilimler Enstitüsü tarafından onaylanan “Ali b. Süleyman el-Mansûrî ve Meşhur Mısır Tariki Kurrâları” isimli tezden istifadeyle üretilmiştir.

** Dr. Öğr. Üyesi, Kırklareli Üniversitesi İlahiyat Fakültesi Tefsir Anabilim Dalı, Kırklareli/Türkiye, ahmetgokdemir81@hotmail.com, orcid.org/0000-0002-5436-0541 


\title{
"Tariq"s, "Meslek"s and Their Resources in the Field of "Qiraah" (Quranic Recitation) Education in Ottoman Era
}

\begin{abstract}
The article deals with "Tariq"s, "Meslek"s and their resources in the field of "Qiraah" (Quranic Recitation) education in Ottoman era. Under the title, "Tariq"s it is touched upon the meaning of "Tariq", varieties of classifications of "Tariq"s and their condition in Ottoman era. As for the title "Mesleks", it includes the information about the respective founders of the "Meslek"s and their resources. The purpose of writing the article is revealing the ways of implementation of "Tariq"s in Ottoman "Qiraah" education and if available to unveil the distinction points from the earlier application. The scope of section "Mesleks" -unlike similar articles written in this field- is to handle the founders and the main resources of these "Meslek"s in detail. It is concluded in the article that there were differences in application ways and naming the "Tariq"s comparing to earlier times. As for the section "Mesleks and their resources" it is inferred that the resources mentioned in the article are more likely to be about the "Tahrirat" (registering of references) field of the "Qiraah".
\end{abstract}

Keywords: Ottoman, qiraah, tariq, meslek, tahrirat. 


\section{Giriş}

Hz. Peygamber'den Osmanlı'ya kadarki dönemde kıraat eğitimi metotları, tarik adı altında değişik sınıflandırılmalara tabi tutulmuştur. Tasnif sonucu oluşan metotlar bazen kıraat âlimlerinin işledikleri müfredat ve okuttukları kıraat kitaplarına göre isimlendirilmiştir. Osmanlı'da ise tariklerin uygulanmasında veya isimlendirilmesinde öncesine göre birtakım değişiklikler söz konusu olabilmiştir. Bununla beraber Osmanlı kıraat eğitiminde uygulanan teknikler, işlenen müfredat ve kitaplara göre de birtakım farklılıklar söz konusu olmuştur ki bu farklılıklara da tarik adı verilmiştir.

Zamanla Osmanlı kıraat eğitiminde İstanbul ve Mısır tarikleri içinde meslekler ortaya çıkmıştır. Bunlar İstanbul tarikine mensup Îtilâf ve Sûfî meslekleri ile Misır tariki bünyesinde bulunan Şeyh Atâullah ve Mutkin meslekleridir. Bahsi geçen oluşumunda bulundukları tarikin azimet ve ruhsat yönlerini tercih etmeleri etkili olmuştur. Mesleklerin istifade ettiği kaynaklara gelince bu eserler daha ziyade tahrirat tarzında kaleme alınan eserlerdir.

Osmanlı'da tariklerin uygulanmasındaki değişikliklerde kıraat eğitimine verilen değerin azalmasının ve kıraat talebelerinin geçim endişesinin rolü büyük olmuştur. Bunun sonucunda zamanla kıraat alanındaki talebe sayısında ve kalitesinde düşüş yaşanmıştır. Bu durum tariklerin uygulanmasında birtakım değişikliklerin ortaya çı1kmasına sebep olmuştur.

Aşağıda tariklerin ne anlama geldiği, sistematize edilmesi, Osmanlı'da uygulama ve isimlendirmeler hususundaki değişim durumları ve bu değişikliklerin sebepleri gibi hususlara değinildikten sonra meslekler konusuna değinilecektir. Meslekler bahsinde ise Osmanlı kıraat meslekleri kurucuları, bu kişilerin kıraat ilmindeki konumları, mesleklerin temel kaynakları, kaynakların genel özellikleri ile içeriklerine değinilecektir.

\section{Tarikler}

Tarik sözcüğ̈̈, gidilen yol, yöntem, usûl ve metod anlamlarına gelir. Kiraat ilmi açısından ise Bezzî (ö. 250/864) rivâyetinin Ebû Rebîa (ö. 294/906) ile İbnü'l-Habbâb tarikleri ve Kunbül (ö. 291/903) rivayetinin İbn Mücâhid ile İbn Şenebûzî (ö. 388/998) tariklerinde olduğu gibi ravilerden sonra gelen farklı okuyuşlar akla gelir ki bu farklılıklar rivayetin sahibine izafe edilir. ${ }^{1}$ Tarik kelimesinin kıraat ilminde bir diğer anlamı ise kıraat âlimlerinin derslerde kendi istekleriyle ya da mecburi olarak işledikleri müfredat, okuttukları kıraat kitabı ya da 
metodudur. ${ }^{2}$ Ayrıca kıraat dersi veren hocalar ile talebelerinin sahip oldukları ilmî düzey ve sayılarına göre kıraat ilminde zaman zaman bu ilmin değişik yönlerini ele alan farklı usûl ve yöntemler uygulana gelmiş ve bunların hepsine birden tarik denilmiştir. ${ }^{3}$

Tarikler değişik açılardan tasnife tabi tutulmuştur. Mesela tariklerden kıraatlerin tahsiline yönelik olanları semâ', arz ve edâ tarikleri şeklinde tasnif edilmiştir. Bunlardan semâ‘ tariki uygulamasında öğrenci dersini hocasından dinlemek sûretiyle alır. Bu tarik daha ziyade mütekaddimûnun kıraat eğitim metodudur. ${ }^{4}$ $\mathrm{Bu}$ tarz eğitimde hocanın talebeleri için yapmış olduğu örnek okuyuşu esastır. Ancak bu durum zamanla azalıp yerini öğrencinin yanlışlarını tashihe bırakır. Kıraatleri tahsile yönelik izlenen yöntemlerden bir diğeri arz tarikidir. Bu tarikin uygulanmasında öğrenci dersini hazırlayıp hocasına okur. İlk dönemlerden itibaren bu metodun icrasinda talebeden dersini ezbere arz etmesi beklenir. Her ne kadar bugün de bu şekilde arz metodunun uygulanması hususunda taviz vermeyen hocalar bulunsa da dersini ezberden okumayı mushafa veya kürrâse ${ }^{5}$ denilen ders hazırlık notlarına bakarak talebenin arzına müsaade eden hocalar da mevcuttur. Zikri geçen tasnife ait edâ tariki ise semâ' ve arz tariklerinin birlikte uygulanması şeklinde icra edilir. ${ }^{6}$

Tariklerin bir diğer tasnifi kıraatlerin uygulamasına yöneliktir. Bu şekilde tasnife tabi tutulan tariklerin ilki infirâddır. Bu usûlde kıraatlerin her birinin imamları ve râvilerinin usûlleri öğretilerek her biri için hatim yapılır. Bu tarz eğitim uzun zaman alabilir. Şâtıbî’nin (ö. 590/1194) infirâd yöntemiyle, talebelerine önce her bir imamın tek tek râvilerini sonra da iki râvinin okumalarını bir araya getirerek, imamların kıraatlerini okutma şeklinde yedi imam için yirmi bir hatim yaptırdığı kaynaklarda aktarılmaktadır.7 İbnü'l-Cezerî’ye (ö. 833/1429) göre bu tarz bir eğitim "cem'u'l-cümû" " tariki için gereklidir. Bahsi geçen tarik ise tüm kıraatler ve rivâyetlerinin infirâd tarikiyle okutulup sonrasında da hepsinin kıraatlerinin tek bir hatim içinde bir araya getirilmesi usûlüdür. ${ }^{8}$

2 Ali Osman Yüksel, “İbnü’l-Cezeri’nin Tayyibetü’n-Neşr’’i ve Özellikleri”, Marmara Üniv. İlahiyat Fak. Dergisi, 7-10 (1989-1992): s. 286-287.

3 Atilla Akdemir, Kıraat İlmi Eğitim ve Öğretim Metodları, İstanbul, İFAV Yayınları, 2013, s. 97.

4 Sultan Muhammed Aliyyü'l-Kārî, el-Minehü'l-fikriyye bi şerhi Mukaddimeti'l-Cezeriyye, Kahire, Matbaatü'l-Meymeniyye, 1308, s. 18.

5 Kürrâseler hakkında geniş bilgi için bkz. Akdemir, Kıraat İlmi, s. 174.

6 Akdemir, Kıraat İlmi, s. 97-100.

7 İbnü'l-Cezerî, Neşr, Beyrut: Dârul Kütübi'l-İlmiyye, t.y., II, s. 195-196.

8 Ebû Bekir Ahmed b. Muhammed, Şerhu Tayyibeti'n-neşr, Kahire, Dâru's-Sahâbe li't-Türâs, 2005, s. 198-199. 
Kıraatlerin tek tek veya bir arada okutulmasıyla ilgili bir diğer usûl de indirâc usûlüdür. Bu usûlde ise kıraatler ve rivâyetleri bir arada yani bir hatimde okutulur. Bu şekildeki bir eğitimin cem'ul-cümû' tarikinden farkı, eğitime başlamadan önce diğerindeki gibi imamlar ve râvilerinin tek tek ve uzunca bir zamanda okutulup birleştirilmesi değil de kısa bir mukaddime ve usûl bilgilerinden sonra doğrudan hatime başlanmasıdır. Hicrî V. asra kadar infirâd usûlüne göre eğitim verilirken, daha sonra kıraat sahasında az zamanda daha çok öğrenmek isteyenler indirâc tariki denilen usûle geçmişlerdir. Ancak bu usûlde rivâyetler ile tariklerin iyice anlaşılmadan okunmasına müsaade edilmemiş, bu tür bir eğitim rivâyetler ve tarikleri karıştırmayacak istidada sahip olanlar için söz konusu olmuştur. ${ }^{9}$

Osmanlı kıraat eğitiminde indirâc tarikinde 'aşere eğitimi verilirken bazı yöntem değişiklikleri olmuştur. Önceleri seb'a tarikinde yedi imam ve imamların râvilerinin sıralamasında çok fazla sorunla karşılaşılmamıştır. Ancak 'aşere tarikinde on imamın râvileri takrîbde ise râvilerin de râvileri olan tarikler devreye girince; indirâc tarikinin uygulanışında, önceleri metin ezberi yöntemiyle ders verilirken sonraları kürrâse denilen ders defteri takibi şeklinde metod değişikliğine gidilmiştir. Bu yöntemde her bir tarik ve meslek kendi usûlünce birtakım kürrâseler hazırlama yoluna gitmiştir. ${ }^{10}$ Kütüphanelerde görülen yüz yıl öncesine ait kıraat kürrâseleri denilen eserler bu durumun örneklerindendir. Örneğin Marmara Üniversitesi İlahiyat Fakültesi Kütüphanesi nr. 1558'de bulunan Giridî’ye (ö. ?) ait Sûfî mesleğine göre hazırlanmış kürrâse denilen metin ve aynı kütüphanedeki birçok kürrâse ile Süleymaniye Kütüphanesi'ndeki onlarca kürrâse bu durumun örneklerindendir.

Kıraat ilmine verilen değerin son zamanlarda azalması, kıraat eğitimi almak isteyen talebe sayısındaki düşüş, kıraat ilminin kaynak metinlerinin ezberlenmesi hususundaki ihmaller, indirâc tarikindeki uygulamaya yönelik böyle bir değişimin nedenleri arasında sayılabilir. ${ }^{11}$ Ayrıca kıraat eğitimi taliplilerinin Arapça konusundaki eksiklikleri de bu soruna zemin hazırlamaktadır. Kürrâselerin ortaya çıkmasından önce kıraat âlimlerinin icâzetnâmelerinde Ali b. Süleyman el-Mansûrî'nin (ö. 1134/1721) talebesi Hasan Efendi (ö. 1136/1723-24) ${ }^{12}$ ile Hüseyin Efendi'nin (ö. 1163/1750) icâzetlerinde ${ }^{13}$ olduğu gibi kıraat ilmiyle birlikte

9 İbnü'l-Cezerî, Neşr, s. 196.

10 Akdemir, Kıraat İlmi, s. 104.

11 Akdemir, Klraat İlmi, s. 103-104.

12 Ali b. Süleyman el-Mansûrî, İcâzetnâme, Süleymaniye Ktp., Reşid Efendi Blm., nr. 24, vr. 97b.

13 Ali b. Süleyman el-Mansûrî, İcâzetnâme, Muhammed b. Suûd Üniv. Ktp., nr. y. 
dinî ilimlerdeki eğitimlerine de değinilmesi, hayatlarıyla ilgili bilgilere bakıldığında birçoğunun medrese icâzetinin de bulunmasi ${ }^{14}$ ve bugün dahi kürrâse yöntemiyle eğitim verilen kurumlardaki talebelerin Arapça ile ilgili problemlerinin olması zikri geçen düşünceyi destekler mahiyettedir.

Tariklerin bir diğer gruplandırılma sistemi, kıraatlerin kendisine nispet edildiği kurrânın sayısına göre oluşturulmasıdır. Buna göre Dânî’nin (ö. 444/1053) yedi imama dair Teysîr isimli eseri ile Şâtıbî'nin aynı şekilde yedi imamla ilgili Şâtıbiyye adlı eserini temel alarak gerçekleştirilen eğitim seb'a tariki olarak isimlendirilirken; İbnü'l-Cezerî'nin on kıraat imamına yönelik Tahbîr ile Dürre isimli eserlerini kaynak olarak kullanarak, imamlar ve ikişer râvilerinin okutulduğu metod ise 'aşere tariki olarak zikredilir. ${ }^{15} \mathrm{Bu}$ tarike 'aşere-i suğrâ denildiği de olmuştur. Ayrıca 'aşerede söz konusu olan imamlar, râvileri ile râvilere ait tariklerin okutulmasına, İbnü'l-Cezerî'nin Neşr ve Takrîbü'n-Neşr ile bu eserlerin manzum hale getirilmiş şekli olan Tayyibe isimli eserlerinden yola çıkılarak uygulanmasına dayanan eğitim tarzına da takrîb tariki denir ki bu tarike 'aşere-i kübrâ da denilmiştir. ${ }^{16}$ Hocazâde Ahmed Hilmi (ö. 1332/1914), Ravdatü 'l-kurrâ isimli yazısında kendi zamanında kıraat eğitimine rağbetin azalması ve geçim endişesi gibi sebeplerle bazılarının başka alanlara yönelmesi nedeniyle Osmanlı kıraat eğitiminde takrîb tariki üzere kıraat eğitimi alanların sayısının azaldığına işaret etmektedir. ${ }^{17}$ Şuan kıraat eğitiminde 'aşere ve takrîbin bir bütünün parçaları gibi görülüp 'aşere tarikinden sonra takrîb eğitiminin verilmesi ve 'aşere eğitimi alanların ekserisinin takrîbi de bitirmesi kıraat ilmi açısından bir gelişmedir. Burada şunu da belirtmek gerekir ki bugünün Türkiye'sinde kurrâ sayısına göre oluşturulan tasnifin içinde ele alınan seb'a tariki hâlihazırda okutulmayıp kıraat eğitimine 'aşere tarikiyle başlanılmaktadır.

14 Ahmet Gökdemir'in, “Ali b. Süleyman el-Mansûrî ve Meşhur Misır Tariki Kurraları” isimli tezinin üçüncü bölümünün "Meşhur Mısır Tariki Kurrâları ve Eserleri” başlığında ele alınan birçok kurrânın medrese eğitimleriyle ilgili bilgiler bu düşüncenin tezâhürlerindendir. Bkz. Ahmet Gökdemir, Ali b. Süleyman el-Mansûrî ve Meşhur Mısır Tariki Kurrâları, (doktora, 2017), Yalova Üniversitesi Sosyal Bilimler Enstitüsü. Mesela Mustafa b. Hasen, icâzetnâmesinde dinî ilimlere değinilen kurrâdan biridir. Kendisi sahibi olduğu icâzetnâmede hocasından Telhîsu'l-meânî, ed-Dürer ve'l-ğurer gibi birçok eseri okuduğundan bahseder. Geniş bilgi için bkz. Mustafa b. Hasen el-İslambulî, Mürşidü't-talebe ilâ m 'arifeti turuki 't-Tayyibe, Süleymaniye Ktp., Hacı Selim Ağa Blm., nr. 29, vr. 68a.

15 Hocazâde Ahmed Hilmi, "Ravdatü'l-kurrâ", Sırât-ı Müstakîm Mecmuası, VI/148, s. 275.

16 Yüksel, “İbnü'l-Cezeri’nin Tayyibetü’n-Neşr'i’, s. 292.

17 Ahmed Hilmi, "Ravdatü'l-kurrâ”, s. 275. 
Tariklerin tasnifinde med mertebelerine göre tariklerin sistematize edildiği de olmuştur. Buna göre med mertebelerinde kasrı yok sayıp sadece tevessut ile tûlu uygulayan tarike mertebeteyn tariki denilmişken; med mertebelerini füveyka'l-kasr, tevessut, füveyka't-tevessut ve tûl şeklinde icra eden tarik ise merâtib-i erbaa tariki şeklinde isimlendirilmiştir. ${ }^{18}$

Bazı tariklere tedris müfredatındaki temel eserlere göre isim verilmiştir. Şöyle ki İmam Şâtıbî'nin Hırzü'l-emânî isimli eserini kaynak edinmek suretiyle kırâ'ât-i seb 'ayı yani imamları, imamların râvilerini usûl ve ferş yönünden takip eden tarik Şâtıbiyye tariki olarak isimlendirilirken; Ebû Amr ed-Dânî’nin Teysîr isimli eserini kırâ'ât-i seb'ada temel alan tarike ise Teysîr tariki denmiştir. Aynı şekilde İbnü'l Cezerî’nin kıraatleri ona tamamladığı Tahbîr adlı eserini gözeterek yapılan eğitime Tahbîr tariki ve yine aynı müellifin yazmış olduğu Dürre'yi kaynak olarak kullanan usûl de Dürre tariki ismiyle zikredilmiştir. Kaynağına izafe edilen tarikler arasında bir de Tayyibe tariki bulunmaktadır ki bu tarikde İbnü'l-Cezerî'nin Neşr ve Takrîbü'n-Neşr isimli eserleri esas alınır. İbnü'l-Cezerî bu iki eseri Tayyibe adlı eserinde nazım haline getirmiştir. Bu tarzdaki eğitim metoduna Tayyibe tariki denir. Tayyibe tariki daha ziyade 'aşere-i kübrâ denilen takrîbde kaynak eser olarak kullanılmıştır. ${ }^{19}$

Sayılan tüm bu tariklere Hâmid b. Abdülfettâh el-Paluvî'nin (ö. 1173/1759) Zübdetü'l- 'irfân adlı eserinin temel alındığı Zübde tariki de eklenebilir. Zira Paluvî, Zübde isimli eserini 'aşere tariki için İmam Şâtıbî ile İbnü’l-Cezerî’nin eserleri başta olmak üzere, temel kıraat kaynaklarından istifadeyle Mısır ve İstanbul tarikinin muhtevâsını ortaya koyacak şekilde hazırlamıştır. ${ }^{20}$ Ayrıca eserinde kıraat vecihlerini klasik kıraat kitaplarındaki gibi sûre ve ayet tertibini gözeterek, k1saca ve anlaşılması kolay olacak bir biçimde ele almıştır. Paluvî’nin Zübde isimli esriyle müsemma bu tarik Osmanlı'ya has bir tariktir. ${ }^{21}$

Tüm bu sayılanlarla birlikte Osmanlı kıraat eğitiminde Mahir ${ }^{22}$ ve Kabâkıbî tariklerinden de bahsedilir. Hocazâde Ahmed Hilmi daha önceleri Mâhir tariki ile Kabâkıbî tarikine göre de eğitim verilirken; kendi zamanında bu iki tarike göre

18 Bennâ, İthâfu fuzalâi'l-beşer, (thk. Şaban Muhammed ), Beyrut, y.y., 1987, I, s. 158-159.

19 Mehmet Adıgüzel, "Kıraat İlminde Tarik-Senet Boyutu ve Konu İle İlgili Te'lif Edilen Eserler”, Atatürk Üniv. Illahiyat Fak. Dergisi, 16 (2001): s. 249-251.

20 Mehmet Emin Maşalı, "Osmanlı Dönemi Tefsir Usûlü Çalışmaları”, Başlangıçtan Günümüze Türklerin Kur' ân Tefsirine Hizmetleri, (Tebliğler ve Müzakereler), İstanbul, y.y., 2011, s. 293-294.

21 Mustafa Atilla Akdemir, "Kıraat Eğitiminde Tarikler”, Abdurrahman Gürses Anısına I. Kur' ân ve Kıraati Sempozyumu, Sakarya, Sakarya Üniv. İlahiyat Fak. Yay., 2000, s. 171.

22 Bkz. Mustafa b. Hasen İslambulî,, Mürşidü 't-talebe, Süleymaniye Ktp., Hacı Selim Ağa Blm., nr. 29, vr. $76 \mathrm{a}$. 
icâzet alan kişi sayısının yok denilecek kadar azalması sebebiyle üzüntüsünü dile getirir. ${ }^{23} \mathrm{Bu}$ iki tarikden Kabâkıbî tariki Şemsüddîn Muhammed b. Halîl el-Halebî'nin (ö. 849/1445) Mecma 'u's-Sürûr ve matla 'u'ş-şümûs ve'l-büdûr isimli on dört kıraate dair manzum eserini esas alan tariktir. ${ }^{24}$ Osmanlı' da önceleri uygulanıp zamanla unutulan tariklerden ikincisi de Mahir tarikidir. İcâzetlerde Mâhir tarikinden bahsedilmektedir. Ancak şu ana kadar yapılan incelemelerde bu tarikin mahiyetiyle ilgili bilgiye henüz ulaş1lamamıştır. Hocazâde Ahmed Hilmî’nin Ravdatü'l-kurrâ isimli yazısı ve Mustafa İslambulî’nin icâzetnâmesinden anlaşıldığına göre Mâhir tariki mütevâtir ve meşhur kıraatlere yöneliktir. ${ }^{25}$

Mısır, İstanbul, Meşârika, Meğâribe ve Irakiyyûn şeklinde bölgelere izafe edilerek tasnif edilen tariklere gelince bu tarikler bulundukları yerlerde meşhur olmuş kurrâ, kıraat eğitim tarzları ve yetiştirmiş oldukları talebeler vesilesiyle bulundukları bölgelerde yaygınlaşarak o bölgenin isimleriyle anılır olmuştur. Mesela Basra, Kûfe ve yakın çevrelerinde yaygın bulunan ekole Meşârike ekolü denilmiştir. Yine aynı şekilde Ahmet el-Mesyerî'nin (ö. 1006/1598) İstanbul'da öncülük yaptığ1 ve öncesinde Teysîr tariki olarak bilinen eğitim metoduna zamanla İslâmbol sonrasında İstanbul tariki denmeye başlanmıştır. Aslında İstanbul ve Irâkiyyûn tariki denildiğinde Meşârike ekolü kastedilmektedir. ${ }^{26}$ İstanbul tarikinde Ebû Amr ed-Dânî'nin Teysîr isimli eseri ile İbnü'l-Cezerî'nin Tahbîru 't-Teysîr'i asıl kaynak olarak kullanılırken İmam Şâtıbî'nin Hırzü'l-emânî diye de bilinen Şâtıbiyye adlı eseriyle İbnü'l-Cezerî'nin Dürre'si yardımcı kaynak olarak kullanılmıştır. ${ }^{27}$

Yine aynı şekilde İbnü'l-Cezerî'den, Şâtıbiyye tarikine göre kıraat öğrenen öğrencileri Hicaz, Yemen, Mısır, Fas, Şam, Cezayir ve Tunus'ta bu tariki yaygınlaştırmıştır. Dolayısıyla bu ekole ravi ve kaynaklarına nispeten Meğâribe

23 Ahmed Hilmi, "Ravdatü'l-Kurrâ", s. 275. Bazı icâzetlerde bu iki tarikin izine rastlamak mümkündür. Bkz. Mustafa İslambulî, Mürşidü t-talebe, vr. 76a.

24 Eser için bkz. Şemsüddîn Muhammed b. Halîl el-Halebî İbnü'l-Kabâkıbî, Mecma 'u s'sürûr ve matla 'u'ş-şümûs ve'l-büdûr, Süleymaniye Ktp., Bağdatlı Vehbi Blm., nr. 31; Köprülü Fâzıl Ahmed Paşa Blm. nr. 27. Ayrıca aynı müellifin Mecma‘ isimli eseri için yazdığı Îzâhu'r-rumûz ve miftâhu'l-künûz adlı şerhi de vardır. Eser için bkz. Şemsüddîn Muhammed b. Halîl el-Halebî İbnü'l-Kabâkıbî, İzâhu 'r-rumûz ve miftâhu'l-künûz, Süleymaniye Ktp., Kılıç Ali Paşa Blm., nr. 23; Fâzıl Ahmed Paşa Blm., nr. 19.

25 Bkz. Ahmed Hilmi, "Ravdatü'l-Kurrâ”, s. 275; Mustafa İslambulî, Mürşidü 't-talebe, vr. 64b.

26 Muhammed Emin Efendi, Zühru'l-erîb fî îdâhi'l-cem 'i bi 't-takrîb, Süleymaniye Ktp., İbrâhim Efendi Blm., nr. 11, vr. 213a.

27 Ahmed Hilmi, "Ravdatü'l-kurrâ", s. 275. 
ekolü denmiştir. ${ }^{28}$ Nâsıruddîn et-Tablâvî'nin talebelerinden Şehâze el-Yemenî (ö. 970/1562) vasıtasıyla Şâtıbiyye tarikinin Mısır' da yaygınlaşması bu durumun örneklerindendir. Şâtıbiyye tariki diye bilinen eğitim sistemini Mısır şeyhülkurrâlarından Şehâze el-Yemenî'nin adı geçen yerde yapmış olduğu kıraat hizmetini yaygınlaştırması sebebiyle, bu tarik zikri geçen bölgede Mısır tariki olarak anılmıştır. Bahsi geçen tarik Mısır'dan Osmanlı'ya gelen Ali b. Süleyman el-Mansûrî vesilesiyle Osmanlı ilim camiasında İstanbul tariki gibi yaygınlık kazanmıştır.

Her ne kadar İstanbul tarikine mensup zevattan hac dönüşü Misır'a gidip de aslında Şâtıbiyye tariki olan Mısır tarikini öğrenenler olmuşsa da Mısır tarikinin Osmanlı kıraat camiasında yaygınlaşması Mansûrî vesilesiyle olmuştur. Osmanlı'da Mısır tarikine mensup kıraat âlimlerinin büyük çoğunluğunun icâzetnâmesindeki silsilenin Ali b. Süleyman vesilesiyle Yemenî ve sonrasında İbnü’l-Cezerî’ye dayanması bu durumun göstergesidir. ${ }^{29}$ Abdülhamit Görücü gibi ${ }^{30}$ Mısır tariki icâzetnâmesine sahip kurrâdan çok az bir kısmının icâzetinde Mansûrî yerine Ahmed el-Eskātî’nin (ö. 1159/1746) ismi geçse de bu durum nadirattandır. Bu tarikte İmam eş-Şâtıbî'nin Şâtıbiyye isimli eseriyle İbnü'l-Cezerî'nin Dürre'si asıl kaynak olarak kullanılırken, Ebû Amr ed-Dânî'nin Teysîr adlı eseri ile İbnü'l-Cezerî'nin Tahbîr' inden de yardımcı kaynak olarak istifade edilmiştir. ${ }^{31}$ Takrîb eğitiminde ise İbnü'l-Cezerî'nin Tayyibe ve Takrîbü'n-Neşr isimli eserlerine müracaat edilmiştir. ${ }^{32}$

İstanbul tariki ile Mısır tarikinin genel itibariyle kullandığı kaynaklar arasında fark olmamakla birlikte bu kaynakların temel veya yardımcı kaynak olarak kullanılması hususunda farkl11ıklar mevcuttur. Mesela İstanbul tarikinin asıl kaynak kabul ettiği kitaplar Mısır tarikinde yardımc1 kitap olarak kullanılırken; aynı şekilde Mısır tarikinin temel kaynaklarından da İstanbul tariki mensuplarınca yardımcı kitap olarak istifade edilmektedir.

28 Emin Efendi, Zühru'l-erîb, vr. 213a-214b.

29 Bkz. Ahmed Hilmi, "Ravdatü'l-kurrâ”, s. 275; İsmâil Karaçam, Kur'ân'ın Nüzûlü ve Kıraati, İstanbul: Nedve Yay., 1981, s. 249-250. Mustafa İslambulî’nin Mürşidü 't-talebe isimli eserinde hem Misır tariki hem de İstanbul tarikinin silsilesinin İbnü'l-Cezerî'ye kadarki kısmında geçen kurrânın isimleri ve hayatlarıyla ilgili bilgiler vardır. Bkz. Mustafa İslambulî, Mürşidü't-talebe, vr. 64a-72b.

30 Bkz. Durmuş Arslan, “Abdülhamid Rüştü (Görücü) Efendi (1860-1923) ve İcâzetnâmeleri”, Cumhuriyet Üniv. Illahiyat Fak. Dergisi, 1 (2011): s. 416. Ayrıca Köprülüzâde Fâzıl Ahmed Paşa da Ahmed el-Eskātî’den ders almıştır. Bkz. Mehmed Tâhir Bursalı, Osmanlı Müellifleri, (hzr. Ali Fikri Yavuz- İsmail Özen), İstanbul: Meral Yayınları, t.y., I, s. 263.

31 Ahmed Hilmi, "Ravdatü'l-kurrâ", s. 275.

32 Muhammed Emîn er- Rûmî, Umdetü'l-hullân fì îzâhi Zübdetü'l-İrfân, İstanbul, Âsitâne, t.y., s. 6. 
Kaynakların kullanımı ile beraber vecihlerin sıralamasında da tarikler arasında birtakım farklılıklar mevcuttur. Bu farkl1lıklardan bir kısmı med mertebeleri ile alakalı iken bir kısmı da usûle dairdir. Mesela İstanbul tarikinin Îtilâf mesleğince merâtibi erbaada fuveyka'l-kasr, tevassut, fuveyka't-tevassut ve tûl ölçüleri sırasıyla 2-3-4-5 iken; Mısır tarikinin Mutkin mesleğine göre ise 1,5-22,5-3'tür. ${ }^{33}$

İstanbul tarikiyle Mısır tarikinin usûle dair farklılıklarına gelince bunlar daha ziyade isti'âze-besmele vecihleri ve ayetlerdeki vücûhâtın takdimleriyle ilgilidir. Mesela İstanbul tariki, isti'âze ve besmele vecihlerinde erbaa merâtibde vasl vecihlerini takdim ederken; Misır tariki ise erbaa merâtib ve mertebeteynde kat' vecihlerini önceler. Yine âyetlerde erbaa merâtibde İstanbul tarikinde Kālûn'un (ö. 220/835) cemi‘ mimlerinde sıla iskâna takdim edilirken Misır tarikinde ise iskan sıladan önce gelir. Ancak mertebeteynde İstanbul tarikinin vecihleri de Misır tarikinin vücûhâtı gibidir. ${ }^{34}$

\section{Meslekler}

Ahmet el-Mesyerî ve Ali b. Süleyman el-Mansûrî, Mısır'dan edindikleri kıraat birikimini Osmanlı'ya kazandırmış, aynı zamanda Osmanlı kıraat alanında iki ayrı ekolün temsilcisi olmuşlardır. Her ne kadar bu iki zatın temsil ettikleri ekollere dair temel kaynakların öncelik sonralık sıralamasında değişiklik söz konusu olsa da her iki kıraat âlimi de aynı kaynaklardan istifade etmiştir. Ancak bu iki ekolün eğitim tarzları, cemi' mimlerindeki takdim veya tehirleri, vücûhât sıralamalarındaki farklılıkları, mertebeteyn ya da merâtib-i erba'adan birini ihtiyarları ve görüşler arasında tercih yapmak suretiyle azimet-ruhsat tarafından birini tercihte bulunmalarında olduğu gibi mensubu oldukları tariklerin uygulamalarında birtakım farklılıklar söz konusu olmuş; bunun sonucunda her iki tarik içinde de meslekler oluşmuştur. Söz konusu mesleklerin sayısı her iki tarik için de ikidir. Bunlar İstanbul tarikine mensup Îtilâf ve Sûfî meslekleri ile Misır tariki bünyesinde bulunan Şeyh Atâullah ve Mutkin meslekleridir. ${ }^{35}$

33 Tariklerin med mertebelerine dair farklılıklarıyla alakalı bilgi için bkz. Akdemir, Kıraat Illmi, s. $125-126$.

34 Tariklerin isti‘âze-besmele ve âyetlerdeki vücûhâta dair farklılıklarıly ilgili bilgi için bkz. Akdemir, Kıraat Ilmi, s. 127-128.

35 Emin Efendi, Zühru'l-erîb, vr. 214b. 
İstanbul tarikine mensup bir kısım âlimlerden bir kısmı hac yolculuklarında Misır tarikine göre ders veren âlimlerden kıraat ilmi tahsilinde bulunmuştur. ${ }^{36}$ Meslek mensupları da kendi eğitim metodlarına bağlı kalmalarına rağmen taassupta bulunmayıp yeri geldiğinde âli isnâda ulaşmak için bir diğer meslek dolayısıyla tarikin âlimlerinden ders alabilmiştir. ${ }^{37} \mathrm{Bu}$ durum kendileri için herhangi bir sorun teşkil etmemiştir. Nihayetinde her iki tarikin icâzetnâme silsileleri İbnü'l-Cezerî'ye dayanmaktadır.

Aşağıda Osmanlı kıraat meslekleri, mesleklerin kurucuları ile kaynak kitaplarına değinilecektir.

\section{1. Îtilâf Mesleği}

Mesleğin öncüsü Yûsuf Efendizâde'dir. Bu meslek, Ahmet el-Mesyerî zamanında ya da hemen sonrasında değil de silsilede sırasıyla Evliyâ Mehmed Efendi (ö. 1045/1636), Yûsuf Efendizâde'nin dedesi Yûsuf b. Abdurrahman (ö. 1062/1652) ve babas1 Muhammed b. Abdurrahman'dan (ö. 1130/1717) ${ }^{38}$ sonra gelen Yûsuf Efendizâde (ö. 1167/1754) ile ortaya çıkmıştır. Yûsuf Efendizâde eğitimde azimet metodunu tercih etmiş ${ }^{39}$ ve bu tercihlerini el-Îtilâffì vücûhi'l-ihtilâf isimli eserinde bir araya getirmiştir. Eser aynı zamanda Yûsuf Efendizâde'nin tesis ettiği mesleğe de ismini vermiştir. ${ }^{40}$ Ittilâf mesleğinde kırâât-i seb 'a ve 'aşerede mertebeteyn ile merâtib-i erba'a tariki esas alınırken takrîbde ise erba'a merâtib uygulanmıştır. Bu ekol bahsedildiği üzere İstanbul tarikinin azimet yönünü tercih etmiştir. Azimet metodunda detaylar ruhsat yöntemine göre fazla olduğu için daha çok zaman ve çaba gerektirmektedir. ${ }^{41}$ Osmanlı kıraat sahasında İstanbul tarikinde Ahmet es-Sûfî’nin kurucusu olduğu Sûfî mesleğinin daha çok tercih edilmesinin sebebi de bu durum olsa gerektir.

36 Örneğin Dersiâm Muhammed Efendi, Ahmed el-Mesyerî'den sonradan İstanbul tariki olarak isimlendirilecek Teysîr tariki üzere kıraat okurken; Ali el-Herevî’den de Hac yolculuğunda Osmanlı'da Mısır tariki olarak anılan Şâtıbiyye tarikine göre kıraat dersi almıştır. Bkz. Muhammed İslambulî, Mürşidü't-talebe, vr. 66b-67a.

37 Akdemir, Kıraat İlmi, s. 125.

38 Yûsuf b. Abdurrahman, Yûsuf Efendizâde'nin dedesidir. Evliyâ Muhammed Efendi'nin talebesi olup onun yerine geçmiştir. Yûsufendizâde'nin babası Muhammed b. Yûsuf da Yûsuf b. Abdurrahman'ın talebesidir. Bkz. Yûsuf Efendizâde, Risâle fì ecvibeti'l-mesâil, Süleymaniye Ktp., Fatih Blm., nr. 68, vr. 37a.

39 Ahmed Hilmi, "Ravdatü'l-kurrâ", s. 275.

40 Emin Efendi, Zühru'l-erîb, vr. 214b.

41 Emin Efendi, Umdetü'l-hullân, s. 8. 


\subsubsection{Meslek Sahibi Yûsuf Efendizâde}

İstanbul'un Fatih ilçesi Nakilbent mahallesinde dünyaya gelen Yûsuf Efendizâde'nin babası şeyhülkurrâ Muhammed Efendi, ${ }^{42}$ dedesi ise Amasyalı reîsülkurrâ Yûsufefendi' dir. Asıl ismi Abdullah Hilmi olmakla beraber dedesine nispetle Yûsuf Efendizâde, memleketine nispetle de Amâsî olarak bilinir. Hâfızlık sonrası babasından kıraat dersleri alan Yûsuf Efendizâde'nin icâzeti babası ve dedesi kanalıyla İbnü'l-Cezerî'ye kadar ulaşır. Ayrıca Süleyman Fâzı1 Efendi'nin (ö. 1134/1722) talebesi olan Yûsuf Efendizâde, İbrâhim b. Süleyman el-Bektaşî'den (ö. 1120/1708) ${ }^{43}$ Arap dili edebiyatı ve tefsir; Birgili Kara Halil Efendi'den (ö. $1123 / 1711)^{44}$ hadis, hadis usûlü, tefsir ve aklî ilimler ile Ali b. Süleyman elMansûrî’den aklî ilimlere dâir dersler almıştır. Kendisi ise Benderli şeyhülkurrâ Ebû Bekir Efendi (ö. ?), ${ }^{45}$ Mustafa İzmirî (ö. 1155/1742), Müftizâde Mehmed Sâdık Erzincânî (ö. 1223/1808), ${ }^{46}$ Râgıb Paşa ve Müstakimzâde Süleyman Sâdeddin (ö. 1202/1788) ${ }^{47}$ gibi isimlere hocalık yapmıştır.

Yaklaşık yarım asır camilerde ve medreselerde ders veren Yûsuf Efendizâde'nin tefsir, hadis ve kıraat alanındaki ihtisası sebebiyle Şam ve Hicaz âlimlerinden birçok kişi kendisinden ilim tahsil etmek için talepte bulunmuş; okudukları

42 Yûsuf Efendizâde'nin kıraat ilmindeki İstanbul tarikine dâir icâzeti, babası ve öncesinde Ahmet el-Mesyerî vasitasıyla İbnü'l-Cezerî’ye kadar varır. Bkz. Emin Efendi, Umdetü'l-hullân, s. 115-116.

43 İcazeti Kâdî Beyzâvî’ye kadar ulaşan Bektâşî’den, Arapça ve edebi ilimleri tahsili sonrasında Beyzâvî Tefsiri'ni okumuştur. Bkz. Yûsuf Efendizâde, Ecvibe, vr. 38a.

44 Anadolu kazaskerliği görevinde bulunmuştur. Yûsuf Efendizâde, kendisinden Sahîh-i Buhârî ve hadis usûlü dersleri almıştır. Bkz. Yûsuf Efendizâde, Ecvibe, vr. 39a; İnâye, Süleymaniye Ktp., Nuruosmaniye Blm., nr. 1042, vr. 1 b.

45 Kendisiyle ilgili bilgi bulunamamıştır. Bursalı, Bursa'da medfun olduğunu bildirir. Bkz. Bursal1, Osmanlı Müellifleri, s. 473.

46 Âlet ilimlerine vukûfiyetiyle bilinir. Başta mantık ilmi olmak üzere değişik ilim dallarına dair hâşiyeleri vardır. Bkz. Bursalı, Osmanlı Müellifleri, s. 404. Bir başka kaynakta vefat tarihi 1223/1827 olarak geçer. Bkz. Mustafa Irmak, "Bir Belâgat Kitabı Olarak Mutavvel ve Osmanlı Medreselerinde Okunuş Biçimi Üzerine Bir Risâle”, Marmara Üniv. İlahiyat Fak. Dergisi, 42 (2012): s. 179. Müftizâde lakabıyla bilinir. Bkz. Bursal1, Osmanlı Müellifleri, s. 473.

47 Dedesi Mehmed Müstakim Efendi’ye nisbetle "Müstakimzâde" şeklinde şöhret bulan Süleyman Sâdeddin'in başta tasavvuf olmak üzere dini ilimler, dil-edebiyat ve biyografi alanlarında birçok eseri vardır. Bkz. Ahmet Yılmaz, "Müstakimzâde Süleyman Sâdeddin”, DİA, İstanbul 2006, XXXII, s. 113-115. Müstakimzâde, Tuhfe adlı eserinde hocası Yûsuf Efendizâde için, “...üstadım şeyhülkurrâ, şârihü'l-Buhârî...” şeklinde bahseder. Bkz. Süleyman Sadettin Müstakimzâde, Tuhfe-i hattâtîn, İstanbul: y.y., 1928, s. 13. 
dersler sonrasında, Yûsuf Efendizâde'den ders ve icâzet verme izni almışlardır. ${ }^{48}$ Yûsuf Efendizâde'nin vermiş olduğu bu icâzetlerin özellikle kıraat ilmine dâir olması, kıraat alanındaki behresini göstermiş; babası ve dedesinin kıraat alanındaki meşguliyetleri muhtemelen Yûsufefendîzâde'de büyük bir etki bırakıp kendisinin de meşguliyetinin daha ziyade bu alana teksifine neden olmuştur. ${ }^{49}$

Yûsuf Efendizâde'nin kıraat ilmi sahasında üzerinde titizlikle durduğu konu, kıraatlerin öğrenilmesinde "fem-i Muhsin" ${ }^{50}$ denilen işin ehlinden müşâfehe söz konusu olmaksızın, sadece kitaplarla iktifâ edilmek sûretiyle öğrenilmemesi gerekliliğidir. Risâle fì ecvibeti 'l-mesâil isimli eserinde bu konuyu dile getiren Yûsuf Efendizâde; müşâfehe olmaksızın kıraat öğreniminin yanlış olduğunu âyetlerden örnekler vermek sûretiyle dile getirmiştir. ${ }^{51}$

Yûsuf Efendizâde kıraat sahasında Osmanlı'nın yetiştirdiği ender şahıslardan biridir. 1718'de Sultan I. Ahmet vakfiyesince Riyâset Kurrâlığı'na, 1721 'de ise Ali b. Süleyman el-Mansûrî'nin yerine Sultanahmet Camii Şeyhülkurrâlığı'na atanmasının yanı sıra; ${ }^{52}$ Osmanlı'da kıraat ilminde iki ana akımdan biri olan "İstanbul tariki" denilen ekolün alt kollarından Îtilâf mesleği’nin kurucusu olması, Y ûsuf Efendizâde'nin, Osmanlı kıraat alanındaki önemini göstermektedir. Ayrıca Sûfî mesleği icâzet zincirinin önemli kesişim noktalarında bulunması, kıraatla ilgili başta Îtilâf isimli eseri olmak üzere birçok eser telif etmesi, Yûsuf Efendizâde'nin bu alandaki yetişmiş otoritelerden biri olduğunun göstergelerindendir. Bununla beraber Saçaklızâde'nin dâd harfine dâir risâlesine reddiye niyetiyle kaleme aldığg 1 Risâletü 'r-reddiye fi'd-dâd isimli eserinde teyit amacıyla o konuyla ilgili daha önce görüş beyan eden birçok âlimin kanaatlerini serdetmesi de kendisinin bu alandaki derin vukûfiyetinin alametlerindendir. ${ }^{53}$

Kıraat ilmi sahasında engin birikime sahip Yûsuf Efendizâde, kıraate dair eserlerinde bu yetkinliğini göstermiştir. Yûsuf Efendizâde'nin kıraatle ilgili eser-

48 Bursalı, Osmanlı Müellifleri, s. 471-472.

49 Ahmet Tobay, "Yusuf Efendizade Abdullah Hilmi ve Hadis Şerhçiliğindeki Yeri", (Yayımlanmamış Doktora Tezi), Marmara Üniv. Sosyal Bilimler Enstitüsü, İstanbul, 1991, s. 51.

50 Fem-i muhsin kavramı için bkz. Mustafa Kılıç, “İmam-Hatip Ortaokul ve Liselerinde Kur'ân Eğitimi Üzerine Bir Araştırma”, Marmara Üniv. Ilahiyat Fak. Dergisi, 47 (2014): s. 77-79.

51 Yûsuf Efendizâde, Ecvibe, vr. 29b.

52 Mehmed Efendi Şeyhî, Vekāyiu'l-fuzalâ, nşr. Abdülkadir Özcan, İstanbul, Çağrı Yayınları, 1989, III, s. 678.

53 Bkz. Yûsuf Efendizâde, Risâle fî harf-i dâdi's-sahîha, Süleymaniye Ktp., Hamidiye Blm., nr. 1261/7, vr. 71-75. 
leri el-îtilâf fì vücûhi'l-ihtilâf, ${ }^{54}$ Risâle fì ecvibeti'l-mesâil mimmâ yetealleku bi vücûhi'l-Kur'ân, ${ }^{55}$ Risâle fì halli ba 'zl'l-işkâlât, ${ }^{56}$ Risâle fì reddi'l-kurââti bi'şşevâz,${ }^{57}$ Risâletü'r-reddiyât fi'd-dât, ${ }^{58}$ Meseletü âl'âne fì 'ilmi vücûhi'l-Kur'ân, ${ }^{59}$ Risâle fì tahkîki ba 'zı vücûhi'l-kırâ' âti fi 'ş-Şâtıbiyye, ${ }^{60}$ Risâle fì vakf-i Hamza, ${ }^{61}$

54 Eserin ismi aynı zamanda İstanbul tarikinin mesleklerinden olan Îtilâf mesleği için de kullanılır. Eser Yûsuf Efendizâde'nin bu ilimle ilgili en önemli eseridir. Osmanlı kıraat ilmi tedrisinin temel kaynaklarından Zübdetü'l- 'irfân adlı eserin kenarında basılmıştır. Eser, kırâât-i aşere imamları, Kur'ân tertibine göre birtakım âyetlerdeki vücûh ve ihtilâfları kapsayıp, Neşr tariki doğrultusunda ele alınmıştır. Bkz. Yûsuf Efendizâde, el-Îtilâf fì vücûhi'l-ihtilâf, Süleymaniye Ktp., M. Hilmi- H. Fehmi Blm., nr. 4-5; Özel Blm., nr. 537/2, vr. 17-92; Ömer Sindel Blm., nr. 53/2 (Ârif Efendi Matbaasında basılmıştır.) Ayrıca bkz. Hamid b. Abdülfettâh Palûvî, Zübdetü'l-İrfân, İstanbul: Hilal Yayınları, t.y., s. r. (Eserin hamiş bölümündedir.)

55 Eseri, Vezir Abdullah Paşa'nın kıraat vücûhâtına dâir soruları üzerine ele alan Yûsuf Efendizâde, kıraat imamlarının bazılarının uygulamalarından örnekler vermek sûretiyle, ibdâl, sıla, nakl ve sekt gibi hususların kıraat vücûhâtında nasıl tatbik edileceğini anlatmıştır. Bkz. Yûsuf Efendizâde, Ecvibe, vr. 29a-39a.

56 Şâtıbiyye ve Teysîr tariki okuyanlar için, Hırzü'l-emânî adlı eserdeki, anlaşılması zor bir kısım beyitleri ele alan Yûsuf Efendizâde, öncelikle beyitleri verip sonrasında beyitlerdeki kıraat vecihlerini dile getirir. Bkz. Yûsuf Efendizâde, Risâle fì halli ba 'zı 'l-işkâlât, Süleymaniye Ktp., İbrâhim Efendi Blm., nr. 66/2, vr. 27-54; Raşid Efendi Blm., nr. 1227/1.

57 Yûsuf Efendizâde, kıraatlerin sahih olması için gerekli olan üç şarttan birini taşımayan şâz k1raatlerin, içinde bulunduğu zaman diliminde camilerde, mescitlerde ve ders takrirlerinde yaygınlaşması sebebiyle bu risâleyi ele almıştır. Yûsuf Efendizâde'nin amacı Kur'ân'ın okunuşunu şâz kıraatlerden arındırmak sûretiyle Kur'ân'ın muhafazasını sağlamaktır. Bkz. Yûsuf Efendizâde, Risâle fí reddi'l-kırâ'âti bi 'ş-şevâz, Süleymaniye Ktp., Fatih Blm., nr. 68/2, vr. 11-22 ve nr. 5328/2, vr. 43b-57b; Laleli Blm., nr. 22/4, vr. 107-118; İbrâhim Efendi Blm., nr. 28/12, vr. 69-81.

58 Arapça'da telaffuzu zor harflerden dât harfiyle ilgili bu risâle, Saçaklızâde’nin, “...dât harfi ile zâ harfi okuma ve işitme hususunda birbirine benzeyip birbirinden farkı yok denecek derecededir" şeklindeki görüşünün serdedildiği, dâd harfiyle alakalı risâlesine cevap mâhiyetinde yazılmıştır. Yûsuf Efendizâde bu risâlede her harfin diğerinden farklı bir sesi olduğunu dile getirir ve bu hususla ilgili Ebû Amr ed-Dânî, Mekkî, Şâtıbiyye şârihi Sehâvî gibi kıraat âlimlerinin görüşlerini delil olarak gösterir. Bkz. Yûsuf Efendizâde, Risâle fi harf-i dâdi 's-sahîha, Süleymaniye Ktp., Hamidiye Blm., nr. 1261/7, vr. 71-75.

59 Yûsuf Efendizâde, eserde vasıl hemzesinin (istifhâm hemzesi ile harf-i ta'rif beyninde olan) durumu ve okunması esnasında sahip olduğu özelliklerden bahseder; kıraat imamlarının vas1l hemzesine dâir vücûhlarından aktarıp الان (Yunus 10/91), الذكريـن (Neml 27/59), الهين (En'âm 6/143-144) kelimelerinin nasıl okunacağını dile getirir. Bkz. Yûsuf Efendizâde, Meseletü âl' $\hat{a}$ ne fì ilmi vücûhi'l-Kur'ân, Süleymaniye Ktp., Laleli Blm., nr. 22/3, vr. 97a-107a.

60 Şâtıbî'nin Hırzü'l-emânî adlı eserindeki bir kısım beyitlerin açıklamalarından ibârettir. Bkz. Yûsuf Efendizâde, Risâle fî tahkîki ba 'zı vücûhi'l-kırâ'âti fi'ş-Şâtıbîyye, Süleymaniye Ktp., Hacı Selim Ağa Blm., nr. 4/2, vr. 87-9; nr. 5/5, vr. 360-399.

61 İmam Hamza'nın vakıflardaki görüşleri ele alınır. Eserle ilgili bkz. Yûsuf Efendizâde, Risâle fî vakf-i Hamza, Süleymaniye Ktp., Mihrişah Sultan Blm., nr. 2/3, vr. 149-161. 
Tuhfetü 't-talebe fì beyâni meddâti turukı 't-Tayyibe'dir. ${ }^{62}$ Bunlardan el-Îtilâffî vücûhi'l-ihtilâf, Îtilâf mesleğinin temel kaynağıdır.

\subsubsection{Mesleğin Temel Kaynağı el-Îtilâf fî vücûhi’l-ihtilâf}

Eser Tayyibe tarikince kırâ'ât-i 'aşereye ve Kur'ân tertibine göre ihtilaf edilen bazı rivâyetlerle vücûhâta dairdir. Tayyibe tarikine göre ele alındığı için kitapta rivâyetlerle birlikte tarikler de söz konusudur. Ancak eserde Kur'ân' da bulunan tüm kelimelerle ilgili vecihler mevcut değildir. Yûsuf Efendizâde'nin eserinde sadece bazı rivâyetler ve vücûhâtları konu edinmesi kendisine bu meyanda yapılan istek sebebiyledir. Eserde daha ziyade هو هانتخ velimelerinde olduğu gibi vücûhât çıkarımının zor olduğu sözcüklerde bulunan ihtilaflara değinilmiş, âyetlerdeki ihtilaflı konular belirtilirken قو له تعالى şeklinde konulara giriş yapılmıştır. ${ }^{64}$

Yûsuf Efendizâde klasik kıraat kitaplarında olduğu gibi önce usûl konularına yer verip daha sonra ferşe dair bazı meselelere değinmek yerine, usûle giriş yapmadan doğrudan Fâtihâ sûresiyle ferşe dair hususları ele almıştır. ${ }^{65}$ Bunları anlatırken de eserinin baş tarafinda mesleğinin ruhsat değil de azimet mesleği olduğunu, dolayısıyla meseleleri böyle bir bakış açısıyla ele aldığını dile getirmiştir. ${ }^{66}$ Mesela Yûsufendizâde Fâtihâ sûresinde bulunan صر اط, الصر اط فرورو kelimelerine و اختلف عن قتبل في الصر اطوصر اط فرواه عنه بالسين ابن مجاهد ورواه عنه بالصاد ابن değinirken يُنبوذ وغيره vermiştir.

Yûsuf Efendizâde, âyetlerde geçen الصر اط, صر اط kelimeleriyle ilgili Hallad'la ilgili vecihleri de zikreden bu hususta Teysîr ve Şâtıbiyye'de birinci kelimenin işmâm, ikinci sözcügün ise adem-i işmâm, Kitâbü'l-Unvân ve Kitâbü'l-Müstenîr' de iki kelimenin de işmâm, Kitâbü'l-Kâfî ve Kitâbü'l-Hidâye'de ise iki sözcügün de adem-i işmâm ile zikredilmesine eserinde yer verir. Yûsuf Efendizâde

62 Yûsuf Efendizâde'nin kıraat imamlarına göre med konusunu ele aldığı eseridir. Yûsuf Efendizâde, eserinde imamların med uygulamalarını Tayyibe tariki doğrultusunda ve imam sıralamasına göre birbirinden bağımsız şekilde incelemiştir. Eserin bir başka özelliği de içeriğinde medlerle ilgili mertebeyn ve merâtib-i erbaa konusuna yer verilmiş olmasıdır. Bkz. Yûsuf Efendizâde, Tuhfetü 't-talebe fì beyâni meddâti turuki 't-Tayyibe, Süleymaniye Ktp., Fatih Blm., nr. 68/5, vr. 39-47, İzmir Blm., nr. 812/3, vr. 20-27'deki eserin de aynı risâle olabileceği düşünülebilir. Ayrıca eser Kasidecizâde bölümü nr. 15/2, vr. 173-180'de geçen Risâle fi beyân-i merâtib-i med; Mihrişah Sultan Blm., nr. 2/2, vr. 132-148'de ise Risâle fi beyâni merâtibi'l-meddât ismiyle geçmektedir.

63 Yûsuf Efendizâde, Itilâf, vr. 25b-26a.

64 Yûsuf Efendizâde, Îtilâf, vr. 37b-a.

65 Yûsuf Efendizâde, Ititlâf, vr. 2a.

66 Yûsuf Efendizâde, Îtilâf, vr. 2 b. 
bu şekilde mesleğinin, kıraatin azimet yönünü temsil yoluyla ele aldığı konularla ilgili görüşlerini tek tek zikreder ${ }^{67}$ ve birçok yerde azimet mesleğini temsil ettiğini hatırlatma gereği duyar. ${ }^{68}$ Ayrıca Yûsuf Efendizâde vecihleri ele alırken söz konusu vücûhâtla ilgili ihtilaflara uzunca değinir ve bu vecihlerle bunların geçtiği eserlerin isimlerini tek tek verir. ${ }^{69}$

Ardından Bakara sûresine geçen Yûsuf Efendizâde, öncelikle Fâtihâ'dan Bakara'ya geçişte söz konusu olan besmele vecihlerine değinir ve bu hususta kurrâdan bazılarını haddi aşmakla niteleyerek, kıraat kitaplarından dayanak göstermek sûretiyle bu konudaki görüşlerini dile getirir. ${ }^{\gamma \cdot}$ Yûsuf Efendizâde kıraat vücûhâtıyla ilgili ihtilafları zikrederken sık sık Şâtıbiyye, Teysîr ve Tayyibe isimli eserlerden iktibasda bulunurken bu eserlerin yanında Kitâbü'l-Unvân, Kitâbü'lKâfî, Kitâbü'l-Hidâye, Kitâbü't-Tizkâr, ${ }^{71}$ Kitâbü'l-Mebhec, ${ }^{72}$ Kitâbü't-Telhîs, Kitâbü't-Tebsira, ${ }^{73}$ Kitâbü'r-Ravda ve Kitâbü'l-Müctebâa ${ }^{74}$ isimli eserlerden de istifade etmiştir. Eserde Teysîr ve Şâtıbiyye'nin من التيسير و الثناطبية şeklinde peş peşe zikredilmesinden yola çıkılarak ${ }^{75}$ kırâ'ât-i seb'a ile ilgili meselelerde Teysîr'i asıl kaynak olarak görüp Şâtıbiyye'yi de Teysîr'deki görüşleri destekleyici mahiyette kullandığı düşünülebilir. ${ }^{76}$ Ancak yer yer vücûhâtla ilgili ihtilaflara değinirken Yûsuf Efendizâde'nin şeklinde önce Şâtıbiyye sonrasında ise Teysîr'i zikrettiği de olmuştur. ${ }^{77}$ Böyle durumlarda bazen في طي şeklinde ${ }^{78}$ ifade ederken muhtemelen Misır tarikinin görüşünü dile getirmiştir. Zira Mısır tarikinde yedi kıraatte Şâtıbiyye asıl, Teysîr ise yardımcı kaynak kabul edilir. Yûsufendizâde bazen de vücûhâtla ilgili bir beldenin genel kabul görmüş görüşleri varsa bu durumda beldelerin kelimelerle ilgili uygulamalarını من طريق المصريين و الثاميين و المغاربة şeklinde dile getirmiştir. $^{79}$

67 Yûsuf Efendizâde, Îtilâf, vr. 2 b.

68 Yûsuf Efendizâde, Itilâf, vr. 3a, 4a.

69 Yûsuf Efendizâde, Îtilâf, vr. 9b-a.

70 Yûsuf Efendizâde, Ititâf, vr. 3a.

71 Yûsuf Efendizâde, Itilaff, vr. 2a-3b.

72 Yûsuf Efendizâde, Ititâf, vr. $4 a$.

73 Yûsuf Efendizâde, Ititlâf, vr. 5b.

74 Yûsuf Efendizâde, Itilâf, vr. 8a.

75 Yûsuf Efendizâde, Ititlâf, vr. 4b.

76 Yûsuf Efendizâde, Itilâf, vr. 5 b.

77 Yûsuf Efendizâde, Itillâf, vr. 8a.

78 Yûsuf Efendizâde, Ititâf, vr. 8b.

79 Yûsuf Efendizâde, Ititlâf, vr. 5a. 
Yûsuf Efendizâde'nin bahsi geçen telifi Zübdedü'l- 'irfân adlı kitabın kenarında basılmakla beraber eserin çok sayıda yazma nüshası da mevcuttur. ${ }^{80}$

\subsection{Sûfî Mesleği}

Mesleğin kurucusu Kastamonulu Ahmed es-Sûfi’dir (ö. 1172/1758). Sûfî mesleği Ahmed el-Mesyerî'den sonra sırasıyla Evliyâ Muhammed Efendi, Şaban Efendi diye bilinen Şaban b. Mustafa (ö. 1097/1686) ${ }^{81}$ ve Sultan Ahmed Camii imamı Muhammed b. Mustafa'nın (Çelebî İmam) ${ }^{82}$ ardından Ahmed es-Sûfi ile ortaya çıkmıştır. Bahsi geçen meslek İstanbul tarikinin ruhsat yönünü tercih eder. Kırâ'ât-i seb'a, 'aşere ve takrîb tarikleri uygulamasında ise mertebeteyn ve erbaa merâtibin her ikisini de icra eder. ${ }^{83}$

Bu mesleğin diğerlerinde olduğu gibi temel kaynak kabul edilebilecek herhangi bir eseri mevcut değildir. ${ }^{84}$ Sadece mesleğin icrasına yönelik kürrâse denilen ve vücûhâtları içeren birtakım defterler kütüphanelerde mevcuttur. ${ }^{85}$ Kütüphanelerde bulunan bu kürrâselerde sık sık Ali b. Süleyman el-Mansûrî'nin Tahrîru't-turuk isimli eseri ve Mustafa b. Abdurrahman el-İzmîrî'nin Bedâyiu'l-burhân'indan nakillerin olması bu eserlerin adı geçen meslekte kaynak olarak kullanıldığı an-

80 Bkz. Yûsuf Efendizâde, Îtilâf, Süleymaniye Ktp., M.Hilmi-F. Fehmi Blm., nr. 5; Özel Yazmalar Blm., nr. 537; Ömer Sindel Blm., nr. 53; Ali İhsan Yurt Blm., nr. 81.

81 Şaban Efendi, Bosna doğumludur. Bosna'da bir müddet kaldıktan sonra İstanbul'a gidip buray1 vatan edinmiştir. Sultan Süleyman Camii imamı Muhammed el-Babâî ile Evliyâ Muhammed Efendi'den kıraat dersleri almıştır. Hocalarından okuduğu kitaplar arasında Şâtıbiyye, Teysîr, Dürre ve Tahbîr gibi kıraat ilminin temel eserleri vardır. Mahmûd Paşa ve Fatih Camii imaml1klarında bulunan Şaban Efendi, Haseki, Süleymaniye ve Ayasofya Camii hatipliği vazifesini de yerine getirmiştir. Bkz. Mustafa İslambulî, Mürşidü 't-talebe, vr. 66.

82 Muhammed b. Mustafa, Şaban Efendi'nin talebelerindendir. Sultan imamı Ebû Bekir Efendi ve Arapzâde diye bilinen Muhammed Efendi gibi birçok kişiye kıraat dersleri vermiştir. Kırâ'ât-i seb'ayı önce infirâd tarikiyle okuyan Mustafa Efendi sonrasında indirâc usûlüyle kıraatleri cem‘ etmiştir. Ardından Şâtıbiyye, Teysîr, Dürre ve Tahbîr eserleri mucibince 'aşere eğitimi alan Mustafa Efendi Kehf sûresi sonuna kadar Tayyibe tarikince erba'a merâtibe göre eğitimine devam etmiş, Kehf sûresinin ardından mertebeteyn usûlünce on dört kıraati okumuştur. Sultan Ahmed Camii imamlığı, Fatih Camii hatibliği ve birçok yerde türbe dârülkurrâsında şeyhülkurrâlık görevlerinde bulunmuştur. Bkz. Mustafa İslambulî, Mürşidü't-talebe, vr. 65a-66a.

83 Emin Efendi, Zühru'l-erîb, vr. 214b.

84 Emin Efendi, Zühru'l-erîb, vr. 214b.

85 Marmara Üniv. İlahiyat Ktp., Üsküdarlı Bölümü nr. 1558'de bulunan Sûfî mesleğine yönelik kürrâse bu durumun örneklerindendir. 
lamına da gelir. ${ }^{86}$ Ayrıca meslekte Muhammed el-Avfî'nin (ö. 1052/1642) Cevâhiru'l-mükellele adlı telifinden de yer yer nakiller yap1lır. ${ }^{87}$ Mesleğin bir başka özelliği İstanbul tarikinin hali hazırda icra edilen tek mesleği olmasıdır. Bunun da Sûfî mesleğinin zikri geçen tarikin ruhsat yönünü tercih etmesinden kaynaklandığı söylenebilir.

\subsubsection{Meslek Sahibi Ahmed es-Sûfî}

Ahmed es-Sûfî ile ilgili kaynaklarda çok fazla bilgi olmamakla beraber kaynaklarda kendisinin Kastamonulu olduğu, ${ }^{88}$ Bostan Camii imamı olup aynı zamanda şeyhülkurrâlık vazifesinde bulunduğ ${ }^{89}$ ve kıraati Çelebi İmam Mehmed Efendi'den (ö. ?) okuduğuna ${ }^{90}$ dair bilgiler vardır. Sûfî'nin bilinen talebeleri Gürcü Osman Efendi (ö. 1204/1789) ${ }^{91}$ ile Hasan b. Vidinî'dir (ö. ?) . ${ }^{92}$ Vefat tarihiyle ilgili verilen bilgilerde farklı11klar söz konusudur. ${ }^{93}$

\subsubsection{Mesleğin Temel Kaynağ ${ }^{94}$}

\subsection{Mutkin Mesleği}

Kettânizâde diye bilinen ${ }^{95}$ Muhammed b. Mustafa en-Na‘îmî'nin (ö. 1169/1755) tesis etmiş olduğu meslektir. Na‘îmî’nin icâzet silsilesi Hüseyin b. Murâd el-Erzurûmî vasitasıyla Ali b. Süleyman el-Mansûrî’ye ulaşır. ${ }^{96}$ Na‘îmî, mensubu olduğu tarikin azimet yönünü tercih etmiştir. ${ }^{97}$

86 Mustafa Atilla Akdemir, Hâmid b. Abdülfettâh el-Paluvî Hayatı, İlmi şahsiyeti, Eserleri ve "Zübdetü'l- 'İrfân” Adlı Eserinin Metodolojik Tanıtımı ve Tahkiki, (doktora, 1999), Marmara Üniv. Sosyal Bilimler Ens., s. 30.

87 Emin Efendi, Zühru'l-erîb, vr. 214a.

88 Akakuş, Reisü'l-kurrâlık, s. 33.

89 Mehmed Süreyya, Sicill-i Osmânî, İstanbul, Türk Tarih Vakfı Yurt Yayınları, 1996, I, s. 166.

90 Ârif b. İbrâhim, Hıfzî, el-Mecmâ' fi'l-kırâ' âti'l-erba 'a, Marmara Üniv. İlahiyat Fak. Ktp., Ali Üsküdarlı Blm., nr. 57, vr. 3b.

91 Hifzî, Mecmâ'; vr. 3b.

92 Akyüz, Osmanlı Kıraat Âlimleri, s. 221.

93 Mehmed Süreyyâ, Ahmed es-Sûfî'nin vefatıyla ilgili 1162/ 1749 tarihini verirken, Molla Mehmed Efendi ise 1172/ 1758 tarihini not düşmüştür. Bkz. Mehmed Süreyya, Sicill-i Osmânî, I, s. 166; Molla Mehmed Emin Efendi, Umde, s. 117.

94 Bahsi geçen meslekle ilgili kaynaklarda diğer mesleklerde olduğu gibi temel kaynak olarak nitelendirilebilecek bir esere rastlanılmamıştır.

95 Emin Efendi, Zühru'l-erîb, vr. 214b.

96 Emin Efendi, Zühru'l-erîb, vr. 215a.

97 Ahmed Hilmi, "Ravdatü'l-kurrâ", s. 275. 
$\mathrm{Bu}$ meslekte medlerin kullanımında ise kırâ'ât-i seb'a, 'aşere ve takrîb tariklerinde mertebeteyn esas olmakla birlikte erba'a merâtibinin de icra edildiği olmuştur. ${ }^{98}$ Mesleğin mensubu olan kimselerin mesleğin icrasında bahsi geçen iki farklı yönelişte olması da bu mesleğin özelliklerindendir. ${ }^{99}$

Mesleğin ismi Kettânizâde'nin Mutkinü'r-rivâye adlı eserinden gelir. Mutkin mesleğinin temel eseri Mutkin olmakla birlikte bu meslekte Ali b. Süleyman elMansûrî'nin Tahrîru 't-turuk adlı eseriyle Mustafa el-İzmîrî'nin Bedâyiu'l-burhân'ından istifâde edildiği de olmuştur. ${ }^{100}$

\subsubsection{Meslek Sahibi Muhammed b. Mustafa en-Naîmî}

Ebû Tâhir Muhammed b. Mustafa en-Na‘îmî, Mısır tariki azimet yönüyle bilinen Mutkin mesleği kurucusudur. Kurucusu olduğu mesleğin adına "Mutkin" denilmesi Na ‘îmî'nin yazmış olduğu eser sebebiyledir. ${ }^{101}$ Kıraat ilmini Ali b. Süleyman el-Mansûrî'nin talebelerinden Hüseyin Erzurûmî'den alan $\mathrm{Na}$ 'îmî, ${ }^{102}$ Üsküdar Selimiye Mektebi muallimliği görevinde bulunmuştur. ${ }^{103}$ Na'îmî'nin kıraat ilmine dair Mutkinü'r-rivâye fî ulûmi'l-kırââti lid-dirâ$y e^{104}$ ve Tehzîbü 't-tilâve fì 'ilmi 't-tecvîdi ve'l-kirâa ${ }^{105}$ isimli eserleri mevcuttur. 1172/1758 y1lında vefat eden Na'îmî, Üsküdar Selimiye Mektebi haziresinde medfundur. ${ }^{106}$

\subsubsection{Mesleğin Temel Kaynağı Mutkinü'r-rivâye fí 'ulûmi'l-kurâati li'd-dirâye}

Eserine Kur'ân'ı hafızların sadırlarına nakşeden Allah'a hamd ve kıraatleri vücûhâtlarıyla zikredip mahiyetleriyle anlatan Hz. Peygamber'e (s.a.v.) salât ile başlayan Muhammed en-Na'îmî, onun ashabını da yedi lügat ile Kur'ân'ı Resûlullah'tan alıp sonrakilere naklettikleri için hayırla anar. Na 'îmî'nin hamd, salat ve ashabı hayırla yad etme tarzından kıraatlere bakış açısı ortaya çıkar. Şöyle ki kendisine göre Resûlullah (s.a.v.) Kur'ân-1 kıraatleriyle nakletmiştir. Ayrıca ese-

98 Emin Efendi, Zühru'l-erîb, vr. 214b.

99 Akdemir, Kıraat İlmi, s. 122.

100 Emin Efendi, Zühru'l-erîb, vr. 215a.

101 Emin Efendi, Umdetü'l-hullân, s. 117.

102 Emin Efendi, Zühru'l-erîb, vr. 215a.

103 Recep Akakuş, Reisü'l-kurrâlık, s. 34.

104 Muhammed b. Mustafa en-Na'îmî, Mütkinü'r-rivâye fì 'ulûmi'l-kırâati li'd-dirâye, Süleymaniye Ktp., Bağdatlı Vehbi Blm., nr. 21, vr. 168b.

105 Muhammed b. Mustafa en-Na'îmî, Tehzîbü'l-tilâve fì 'ilmi 't-tecvîdi ve'l-kırâe, Milli Ktp., Yazmalar Blm., nr. 3405.

106 Akakuş, Reisü'l-kurrâlık, s. 34. 
rin başında sahâbe ile ilgili kısımdan anlaşıldığına göre Na'îmî, yedi harfi yedi lügat olarak görmektedir. ${ }^{107}$

Muhammed en-Na'îmî, eserini bir nevi kıraat ilminin tahrirat kısmıyla ilgili görüp, eserde on kıraati sahih senedle alınmış bir şekilde anlattığını, ele aldığ 1 konuları ise mukaddime, ferş-i hurûf ve hatime bölümleri olmak üzere üç k1sımda incelediğini beyan eder. Eserin mukaddime bölümünde eserin bölümleri ve esere verilen isim gibi kısa bilgiler verildikten sonra Kur'ân ve kıraatin ifade ettiği anlamlar, kıraatlerin mebâdîsi, mevzûu, faidesi, gayesinde olduğu gibi kıraatlerle ilgili genel bilgiler verilmiştir. Ayrıca Kur'ân'ın ezberlenmesi, talim üzere okunması ve kıraatlerinin öğrenilmesi gibi hususların farz-1 kifâye olduğuna dair hususlar ele alınmıştır. Kıraatlerin hadis ilmindeki gibi sadece semâ yoluyla alınamayacağı, bilakis semâ ve müşâfehe ile birlikte öğrenilmesi gerekliliği; çünkü kıraatlerin mana ile rivayet edilemeyip lafızları ve hey'etleriyle birlikte nakledilebileceği konusu da eserde incelenen bir diğer konudur. ${ }^{108}$ Eserde mevcut diğer konu başlıkları ise kıraatlerin kısa bir şekilde oluşum süreçleri, ${ }^{109}$ kıraat, rivâyet, tarik kavramların ifade ettiği anlamlardır. ${ }^{110}$

$\mathrm{Bu}$ bölümde zikri geçen bilgilerden biri de kıraatlerin öğrenilme tarzıdır. Kitapta kıraatlerin tedrisinde Şâtıbiyye adlı eserin ezberlenmesi ile kıraatlerin ilk olarak infirad usûlüyle okunması hususuna özellikle değinilir. Na'îmî, hicrî V. asırdan itibaren bu usûlden vazgeçilip bir hatimde tüm kıraatlerin bir araya getirilerek okunduğunu ve bu durumun kendi zamanına kadar böyle devam ettiğini; ancak infirâd usûlünün şart olduğunu dile getirir. ${ }^{111}$ Müellifin böyle düşünmesinin sebebi ise kıraatlerde tahlîdin oluşma ihtimalidir. Tahlîd ise tahrîmen mekrûh ve haramdır. ${ }^{112}$ Kıraate dair bilgilerden sonra kıraat imamları, imamların ravileri ile tariklere dair bilgiler veren $\mathrm{Na}^{\text {'îmî }}{ }^{113}$ eserinde kıraat imamlarının zikrediliş şekillerine de (rumûzlarına) değinir. ${ }^{114}$

Nâ‘îmî, sûrelerde bulunan ferş-i hurûfa dair bölümde ise sûre başlarında ilgili sûre hakkında bilgi verir. Bunun yanında diğer kıraat kitaplarından farklı olarak sûrelerin Mekkî veya Medenî oluşları ile sûrelerde bulunan ayet, kelime ve harf

107 Mustafa en-Na'îmî, Mutkinü'r-rivâye, vr. 2a.

108 Mustafa en-Na'îmî, Mutkinü'r-rivâye, vr. 2b-a.

109 Mustafa en-Na'îmî, Mutkinü'r-rivâye, vr. 2b-3a.

110 Mustafa en-Na'îmî, Mutkinü'r-rivâye, vr. 2b-3a.

111 Mustafa en-Na'îmî, Mutkinü' r-rivâye, vr. 3b.

112 Mustafa en-Na'îmî, Mutkinü'r-rivâye, vr. 4a.

113 Mustafa en-Na'îmî, Mutkinü'r-rivâye, vr. 4a-5a.

114 Mustafa en-Na'îmî, Mutkinü'r-rivâye, vr. 5b. 
sayılarında olduğu gibi sûrelerin değişik yönleriyle ilgili bilgiler zikreder. Ayrıca sûrede bulunan kırâ'ât-i 'aşereyle alakalı meselelere de değinen Na'îmî, sûredeki resmü'l-mushafa dair konuları ele alır ve resmü'l-mushafla ilgili bilgileri verirken de Ahmed el-Bennâ'nın (ö. 1117/1705) tertîbini takip eder. ${ }^{115}$ Eserle ilgili bu bilgiler Fâtihâ sûresi özelinde örneklenecek olursa; Na'îmî, Fâtiha sûresinin Mekkî veya Medenîliğine dair görüş bildirenlerle, ihtilaflı olmakla birlikte ayetlerin sayısının yedi, sûredeki kelime sayısının yirmi beş ve harf sayısının da yüz

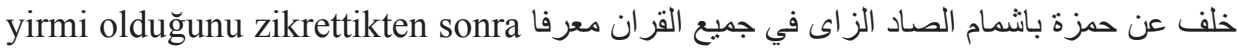
ibaresinde geçtiği üzere sûredeki ihtilaflı kelimelerle ilgili vecihlere değinir. ${ }^{116}$ Daha sonra Fâtiha sûresinde bulunan ملك بغير الف kelimesinde olduğu gibi resmü'l-mushafla alakalı bazı hususları dile getiren müellif, ${ }^{117}$ ferşü'l-hurûfa ait konuları ele alırken Şâtıbiyye ve Dürre isimli eserlerden istifade ile bölümü yazdığını zikreder. ${ }^{118}$

Bölümde ilk ele alınan konu, klasik kıraat kitaplarında olduğu gibi istiâze ve besmele vecihleridir. İstiâze ve besmele ile ilgili vücûhâtlar sonrasında Fâtiha sûresiyle bölüme devam edilir. ${ }^{119} \mathrm{Bu}$ şekilde sırasıyla tüm sûreleri ele alan müellif, bazı yerlerde "Ebü’l-Kâsım eş-Şâtıbî’nin tercihi budur. Hocalarımızdan bu şekilde aldık." ifadelerine yer verir. ${ }^{120}$

Na'îmî, Şâtıbiyye ve Dürre'yi esas almakla birlikte Kitâbü 't-Teysîr, Kitâbü'l-Hâdî, Kitâbü'l-Hidâye, Kitâbü 't-Telhîs, Kitâbü̈t-Tebsıra, Kitâbü'l-Unvân gibi temel kıraat kaynaklarından da yer yer istifade etmiştir. ${ }^{121}$ Ayrıca وناربة ifadelerindeki gibi vecihlerle ilgili beldelerin ve tariklerin görüşlerine de eserde yer verilmiştir. ${ }^{122}$

Müellif, ferşü'l-hurûfa dair tüm sûrelerle ilgili bilgileri sırayla aktardıktan sonra eserin üçüncü ve son bölümü olan hatime bölümüne geçer. Bu bölümde ise Duhâ sûresinden Fâtiha'ya kadarki tekbir vecihlerini zikreder. ${ }^{123}$ Tekbirle ilgili vücûhât sonrasında uzunca bir hatim duası ile esere son verir. ${ }^{124}$

115 Mustafa en-Na'îmî, Mutkinü'r-rivâye, vr. 2a.

116 Mustafa en-Na'îmî, Mutkinü'r-rivâye, vr. 6a.

117 Mustafa en-Na'îmî, Mutkinü'r-rivâye, vr. 6b.

118 Mustafa en-Na'îmî, Mutkinü'r-rivâye, vr. 5b.

119 Mustafa en-Na'îmî, Mutkinü'r-rivâye, vr. 6a.

120 Mustafa en-Na'îmî, Mutkinü'r-rivâye, vr. 7b, 10a.

121 Mustafa en-Na'îmî, Mutkinü'r-rivâye, vr. 34a.

122 Mustafa en-Na‘îmî, Mutkinü'r-rivâye, vr. 59a.

123 Mustafa en-Na'îmî, Mutkinü'r-rivâye, vr. 159a.

124 Mustafa en-Na'îmî, Mutkinü'r-rivâye, vr. 159b. 
Eser, ferağ kaydındaki bilgilere göre 23 Recep 1161'de cuma gününde nihayete erdirilmiştir. ${ }^{125}$

\subsection{Atâullah Mesleği}

Atâullah en-Necîb b. el-Hüseyin'in (ö. 1209/1794) tesis etmiş olduğu M1sır tariki Atâullah mesleğinin kurucusunun icâzet silsilesi, Dülgerzâde İmamı Mahmud Efendi (ö. 1166/1753) ve öncesinde Hocapaşa İmamı Hasan Efendi'nin vasitasıyla Ali b. Süleyman el-Mansûrî'ye ulaşır. ${ }^{126}$ Ad1 geçen meslek Misır tarikinin ruhsat yönünü tercih eder. ${ }^{127}$ Atâullah mesleğinde Kırâ'ât-i seb'a, 'aşere ve takrîb eğitiminde kullanılan med tarikleri ise mertebeteyn ve merâtib-i erba'adır. ${ }^{128}$

Mesleğin icrasında istifâde edilen temel eserler Güllü Hâfiz diye de bilinen Ahmed Rüşdî’nin (ö. 1217/1802-03) Mürşidü't-talebe ${ }^{129}$ isimli eseri ile Ârif Hıfzî'nin Muhtâru'l-ikrâ'sıdır. ${ }^{130}$ Bahsi geçen meslek Mısır tarikinin hali hazırda icra edilen mesleğidir. 1275/1858 tarihinde vefat eden Muhammed Emin Efendi'nin (ö. 1275/1858-59) bildirdiğine göre ${ }^{131} \mathrm{o}$ zamanda da durum bugünkünden farklı değildir. Yani İstanbul tarikinin azimet ve ruhsat boyutunu tercih eden iki meslekten yalnızca Sûfî mesleğinin uygulanmasındaki gibi Mısır tarikinde de ruhsat yönünü tercih eden Atâullah mesleği icra edile gelmiştir. Bu durum adı geçen mesleklerin eğitimde ruhsat vechini benimsemeleriyle ortaya çıkmış olsa gerektir. Hocazâde Ahmed Hilmi'nin dediği üzere kıraat ilmine rağbetin azalması ile bu ilme gönül verenlerin geçim dertleriyle ilgili sıkıntılarının olması bu halin oluşmasının en büyük sebebidir. ${ }^{132}$

\subsubsection{Meslek Sahibi Atâullah en-Necîb (ö. 1209/1794)}

Mısır tariki Atâullah mesleği kurucusu ${ }^{133}$ Atâullah Mehmed en-Necîb b. Hüseyin, Mısır tarikini Osmanlı kıraat ilmi sahasında yaygınlaştıran Ali b. Süleyman el-Mansûrî'nin torunudur. Şeyh Ataullah, Dülgerzâde imamı Mahmud Efendi'den kırâ'ât-i seb'a ve 'aşere dersleri almıştır. Atâullah Efendi'nin kıraat ilmindeki bir

125 Mustafa en-Na ‘îmî, Mutkinü'r-rivâye, vr. 168b.

126 Emin Efendi, Zühru'l-erîb, vr. 215a.

127 Ahmed Hilmi, "Ravdatü'l-kurrâ", s. 275.

128 Emin Efendi, Zühru'l-erîb, vr. 214b.

129 Ahmed Hilmi, "Ravdatü'l-kurrâ", s. 275.

130 Emin Efendi, Zühru'l-erîb, vr. 215a.

131 Muhammed Emin Efendi, Zühru'l-erîb, vr. 215a.

132 Ahmed Hilmi, "Ravdatü'l-kurrâ", s. 275.

133 Emin Efendi, Zührü’l-erîb, vr. 214a. 
diğer hocası Mahmutpaşa hatibi Veliyyüddîn Efendi'dir (ö. ?). ${ }^{134}$ Talebelerinden en önemlileri ise Muhammed Belenî (Şeyh Coşkun) (ö. 1230/1815) ${ }^{135}$ ile Hasan b. Mustafa'dır (ö. ?). ${ }^{136}$ Kurucusu olduğu Misır tariki Atâullah mesleği, adı geçen tarikin ruhsat yönünü temsil eder. Bu mesleğin meselelerini yansitan temel eserler Ahmed er-Rüşdî’nin (ö. 1217/1802) kaleme aldığ1 Mürşidü t-talebe ${ }^{137}$ isimli eseri ile Ârif Hıfzî’nin (ö. 1238/1822) Muhtâru'l-ikrâ'sıdır. ${ }^{138}$

Atâullah Efendi aynı zamanda şeyh olup derslerini Beykoz Kanlıca'daki ${ }^{139}$ Nakşîlere ait Şeyh Atâullah Tekkesi'nde vermiştir. Kendisi Tekkesi'nde bir yandan şeyhlik vazifesini yürütürken diğer yandan kıraat ilmine hizmet etmiştir. ${ }^{140}$

\subsubsection{Mesleğin Temel Kaynakları}

Ahmed er-Rüşdî'nin Mürşidü 't-talebe'si ile Ârif Hıfzî'nin Muhtâru'l-ikrâ isimli eserleri Atâullah mesleğinin temel kaynakları olarak addedilmişlerdir. Aşağıda ismi geçen eserlerin mahiyetiyle ilgili bilgi verilecektir.

134 Süleyman Sürûrî, İcâzetnâme, Süleymaniye Ktp., Galata Mevlevihânesi Blm., nr. 129, vr. 5ba; İsmâil Hakkı Kastamonî, İcâzetnâme, Süleymaniye Ktp., Yazma Bağışlar Blm., nr. 2870, vr. 5b-a.

135 Kastamonî, İcâzetnâme, vr. 5b-a.

136 Atâullah Efendi gibi birçok hocadan kıraat ilmi dersleri alan Hasan b. Mustafa, Ârif Hıfzî gibi tanınmış birçok kıraat âlimini yetiştirmiştir. Bkz. Ârif b. İbrâhim, Hıfzî, el-Mecmâ' fi'lkırâ'âti'l-erba 'a, Marmara Üniv. İlahiyat Fak. Ktp., Ali Üsküdarlı Blm., nr. 57, vr. 3 b.

137 Emin Efendi, Zühru'l-erîb, vr. 215b; Ahmed Hilmi, "Ravzatü'l-kurrâ”, s. 275. Eserle ilgili bkz. Yûsuf İmamzâde Ahmed er-Rüşdî, Mürşidü 't-talebe ilâ îdâhi vücûhi b 'adi âyâti'l-Kur'anniyye, Süleymaniye Ktp., Fatih Blm., nr. 71.

138 Eserle ilgili bkz. Ârif Hıfzî, Muğni'l-kurrâ fî şerhi muhtâri'l-ikrâ, Beyazıt Ktp., Beyazıt Blm., nr. 177.

139 Bahsi geçen yer, Mehmed Atâullah Tekkesi ve Şeyh Atâullah Tekkesi isimleriyle anılır. Geniş bilgi için bkz. M. Baha Tanman, “Atâ Efendi Tekkesi”, DİA, İstanbul 1991, IV, s. 36-37. Atâullah Efendi burada medfundur. Bkz. Abdürrahim Cabir Vada, Boğaziçi Konuşuyor ve Kanlıca Tarihçesi, İstanbul: Kitabevi, 2004, s. 75.

140 Alemdar, Osmanlı'da Dârülkurrâ Müessesesi, s. 119. Dergâhı bu yönüyle kıraat eğitim merkezlerinden kabul edilebilir. İlimden uzaklaşmayı kerih gören bazı şeyh, halife ve tarîkat ehli, dergâhlarının dâhilinde veya yanı başlarında dârülkurrâlar yaptırıp buralarda Kur'ân okutmuşlar veya okutulmasına vesile olmuşlardır. Buralardaki şeyhulkurrâlık görevini ise Şeyh Atâullah en-Necîb (ö. 1209/1794) örneğinde olduğu gibi bizzat dergâhın şeyhi veya halifesi yürütmüştür. Bilgi için bkz. Gökdemir, "Osmanlı Kur’ân Eğitim Merkezleri: Dârülkurrâlar ve Sibyan Mektepleri”, Edebali İslamiyat Dergisi, 1/2 (2017), s. 49. 


\subsubsection{Mürşidü't-talebe ilâ îdâhi vücûhi ba'di âyâti'l-Kur'âniyye}

Eserinin başında kıraat ilmindeki eğitim serüveninden bahseden ${ }^{141}$ Yûsuf İmamzâde, kıraat eğitimi alan bazı talebeler, kendisinden kıraatlerin edası ve okunması hususunda kitap yazımını talep edince, kıraat ilminin tahriratına yönelik bir eser yazarak bu talebe cevap vermiş ve eserinin telifinde Tayfûr es-Secâvendî’nin vakıflarına riayet ettiğini özellikle belirtme gereği duymuştur. Kitabını yazarken tahrirata yönelik üç eserden etkilendiğini belirten Yûsuf İmamzâde, kendi eserini de bir nevi bu üç eserin bir araya getirilmiş hali olarak nitelemiştir. Eserin özelliği öncesindeki tahrirata yönelik eserlerde olduğu gibi Tayyibe tarikince yazılmış olmasıdır. Yûsuf İmamzâde'nin eserini yazarken etkilendiği eserler Ali b. Süleyman el-Mansûrî, Yûsuf Efendizâde Abdullah Hilmi ile Mustafa İzmîrî'nin tahrirata yönelik eserleridir. ${ }^{142}$

Eser bu yönüyle Ali b. Süleyman el-Mansûrî’nin Osmanlı kıraat ilmindeki ve bu ilme dair birikimdeki yerini gösterir. Zira Mansûrî'nin tahriratla ilgili eseri sonrasında Osmanlı kıraat ilmi geleneğinde tahrirata dair telif işi büyük bir merhale kat etmiş ve bu doğrultuda birçok Osmanlı kıraat âlimi tahrirata yönelik eser yazmıştır. Mustafa el-İzmîrî, Hâşim el-Mağribî (ö. 1179/1765-66) gibi tahriratla alakalı eser yazanlara bakıldığında bunların büyük bir kısmının Mansûrî'nin talebesi ya da talebelerinin talebeleri olmaları bu düşünceyi destekler mahiyettedir. ${ }^{143}$

Yûsuf İmamzâde, telifinin tanıtımına yönelik kısa bir girizgâh yaptıktan sonra Fâtiha sûresine giriş yapmış, bu başlık altında önce sûre evvelindeki istiâze ve besmele vecihlerini anlatmıştır. İstiâze ve besmele vecihlerinin tek tek sıralanmas1 sonrasında Fâtiha sûresindeki vecihlere değinen Yûsuf İmamzâde, sûrelerdeki

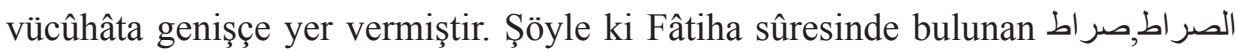
واختلف في الصراط وصر اط فيهما عن خلاد من طريق kelimelerindeki işmâmın hallerini şeklinde zikretmiş ve ara ara tenbih ifadeleriyle izahatta bulunmuştur. Yapılan açıklamalar işmâm örneğinde olduğu gibi vecihlere ait usûl konularındaki tanımlarla ilgilidir. " Mesela Fâtiha sûresindeki işmâm ile ilgili yerde معنى الاشمام هنا خلط لفظ الصاد بالزاى ويعرف بانه مزج الحرف باخر

141 Yûsuf İmamzâde, Hâcızâde Muhammed Efendi'den önce kıraat-i Âsım'ın Hafs rivâyetine göre Kur'ân-1 baştan sona kadar okumuş, sonra Şâtıbiyye, Dürre, Tayyibe ve Mâhir tarikleri mûcibince on kıraati bitirmiş, eğitiminin ardından Fatih Sultan Mektebi'nde talim dersleri vermeye başlamıştır. Bkz. Yûsuf İmamzâde, Mürşidü t-talebe, vr. 2a.

142 Yûsuf İmamzâde, Mürşidü 't-talebe, vr. 2b.

143 Mansûrî ve Osmanlı kıraat ilmine katkılarıyla ilgili geniş bilgi için bkz. Ahmet Gökdemir, Ali b. Süleyman el-Mansûrî ve Meşhur Mısır Tariki Kurrâları, (doktora, 2017), Yalova Üniversitesi Sosyal Bilimler Enstitüsü.

144 Yûsuf İmamzâde, Mürşidü 't-talebe, vr. 3a. 
şeklinde tarifte bulunan Yûsuf İmamzâde; yer yer mesleğimiz azîmet mesleğidir, ruhsat mesleği değildir diyerek mesleğine ait bilgiler de vermiştir. ${ }^{145}$ Fâtiha sûresi sonrasında Bakara'ya geçiş yapan Yûsuf İmamzâde iki sûre arasındaki besmele vecihlerine değinmiştir. ${ }^{\prime ؛}$

Sûrelerdeki vecihlerle ilgili bilgi verileceği zaman Bakara sûresi 11. âyette

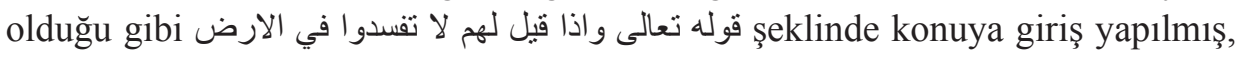
dikkat çeksin diye ayetlerin üstü kırmızı kalemle çizilmiş ${ }^{147}$ ve bazı yerlerde metinle ilgili izah edilmesi gereken durumlarda talikat denilen kısımda açıklama yapılmıştır. ${ }^{148}$ Sûre isimlerinin belirgin bir halde ve kırmızı kalemle yazıldığ 1 eser, Beled sûresine kadarki vücûhâtı içermektedir. ${ }^{149}$

Yûsuf İmamzâde, eserinde Tayyibe, Şâtıbiyye, Teysîr, Kitâbü'l-'Unvân, Kitâbü'l-Müstenîr, Kitâbü't-Telhîs, Kitâbü'l-Kâfî, Kitâbü'l-Hidâye, Kitâbü 't-Tezkira, ${ }^{150}$ Kitâbü'l-Misbâh, ${ }^{151}$ Kitâbü'l-Mebhec, Câmi 'u'l-Beyân ${ }^{152}$ gibi kıraat ilmine dair temel eserlerden ve bu eserlerin müelliflerinin görüşlerinden istifâde etmiştir. Ayrıca tahriratla ilgili eserinde olduğu üzere Yûsuf Efendizâde Abdullah Hilmi’nin Îtilâf, Mustafa İzmîrî'nin Bedâi ‘u'l-burhân'1 gibi bu alana yönelik yazılmış önemli eserlerden de yararlanmıştır. ${ }^{153}$ Eserde diğer kıraat kitaplarında görüldüğü gibi birçok yerde Şâtıbiyye ile Teysîr isimli kitapların yan yana zikredilip sonrasında yer yer diğer kıraat kitapları da yardımcı kaynak mahiyetinde kullanılmıştır. Esasında Yûsuf İmamzâde'nin de temsilcisi olduğu Mısır tarikinde Şâtıbiyye asıldır, Teysîr ise yardımcı kitaptır. Dolayısıyla kendisi de tarikinin uygulaması olarak kırâ'ât-i seb'a'da Şâtıbiyye'den esas kitap olarak, Teysîr'den de bahsi geçen eserdeki görüşleri destek mahiyetinde kullanmıştır. ${ }^{154}$ Ancak bazı yerlerde Teysîr'in, Şâtıbiyye'den önce kullanıldığ ${ }^{155}$ ve bazen de Şâtıbiyye ve Teysîr' in birbirinden ayrı ve diğer kıraat kitaplarıyla birlikte kaynak gösterildiği de olmuştur. ${ }^{156}$ Eserle alakalı bir başka dikket çeken nokta ise müellifin, "Hocama

145 Yûsuf İmamzâde, Mürşidü 't-talebe, vr. 3a.

146 Yûsuf İmamzâde, Mürşidü 't-talebe, vr. $3 b$.

147 Yûsuf İmamzâde, Mürşidü 't-talebe, vr. 7b.

148 Yûsuf İmamzâde, Mürşidü 't-talebe, vr. 9b, 165a.

149 Yûsuf İmamzâde, Mürşidü 't-talebe, vr. 175a.

150 Yûsuf İmamzâde, Mürşidü 't-talebe, vr. 3a.

151 Yûsuf İmamzâde, Mürşidü 't-talebe, vr. 4a.

152 Yûsuf İmamzâde, Mürşidü 't-talebe, vr. 5a.

153 Yûsuf İmamzâde, Mürşidü 't-talebe, vr. 4a.

154 Yûsuf İmamzâde, Mürşidü 't-talebe, vr. 5b-a.

155 Yûsuf İmamzâde, Mürşidü 't-talebe, vr. 5b-6a, 34a.

156 Yûsuf İmamzâde, Mürşidü 't-talebe, vr. 32a, 41b. 
böyle okudum." tarzında ifadelere eserinde yer vermesi ${ }^{157}$ ile Ali b. Süleyman elMansûrî’nin görüşlerini zikretmesidir. ${ }^{158}$

\subsubsection{Muhtâru'l-ikrâ ve Muğni'l-kurrâ fî Şerh-i Muhtâri'l-ikrâ}

Muhtâru'l-ikrâ, Muhammed Arif Hıfzî'nin (ö. 1238/1822) Misır tariki üzere bazı meseleleri ele aldığı yüz on beyitlik manzum eseridir. Eser usûl ve ferşü'l-hurûf bölümlerinden oluşmakta ve Muhtâru'l-ikrâ' ya şerh mahiyetinde yaz1lan Muğni'l-kurrâ isimli eserle birlikte bulunmaktadır. Eserin tespit edilebilen tek nüshası Beyazıt Kütüphanesi Beyazıt Bölümü 177 numarada kayıtlı olan nüshadır. ${ }^{159}$

Muğni'l-kurrâ isimli eser ise Hifzî'nin Muhtâru'l-ikrâ isimli eseri üzerine yine kendisi tarafından yazılan şerhidir. Kitabına kıraat ilmi icâzet silsilesiyle başlayan Ârif Hıfzî, ${ }^{160}$ eserinin içeriğini kıraat sahasının temel eserlerinden Hırzü'l-emânî ve Dürre'ye dair ihtilafların oluşturacağını belirtir. Ardından Hırzü'l-emân̂̂ ve Dürre'nin müellifleriyle ilgili bilgiler ${ }^{161}$ verdikten sonra bazı kelimelerle ilgili tariklerin okuyuşlarına değinen Hıfzî, bu tarikleri oldukça uzun bir şekilde sıralar. ${ }^{162}$ Daha sonra iki sûre arasında bulunan istiâze ve besmele vecihlerini ele alan Hıfzî, bu başlık altında imamların ve ravilerinin iki sûre arasındaki istiâze ve besmeleyle ilgili vücûhâtına değinir. ${ }^{163}$ Hıfzî, istiâze ve besmeleye dair okuyuşlarla alakalı başlıktan sonra sirasıyla cemi ' mimleri, sıla ve idğam, ${ }^{164}$ bir kelimede iki hemze, ${ }^{165}$ hemzenin nakli ile sekit, nakil ve sekt, ${ }^{166}$ Hamza (ö. 156/773) ve Hişâm' ’n (ö. 245/859 [?]) vakıfları hususunda bilgiler verdikten sonra ${ }^{167}$ ferş-i hurûf konusuna geçer. ${ }^{168}$

157 Yûsuf İmamzâde, Mürşidü 't-talebe, vr. 11b, 13b, 33b.

158 Yûsuf İmamzâde, Mürşidü 't-talebe, vr. 32a, 33b.

159 Eser için bkz. Hıfzî, Muğni 'l-kurrâ fì şerhi Muhtâri'l-ikrâ, Beyazıt Ktp., Beyazıt Blm., nr. 177, s. 1.

160 Hıfzî, Şerhu Muhtâri'l-ikrâ, s.1.

161 Hifzî, Şerhu Muhtâri'l-ikrâ, s. 2.

162 Hifzî, Şerhu Muhtâri'l-ikrâ, s. 3-6.

163 Hifzî, Şerhu Muhtâri'l-ikrâ, s. 6-9.

164 Hifzî, Şerhu Muhtâri'l-ikrâ, s. 9-14.

165 Hifzî, Şerhu Muhtâri'l-ikrâ, s. 14-23.

166 Hifzî, Şerhu Muhtâri'l-ikrâ, s. 23-35.

167 Hifzî, Şerhu Muhtâri'l-ikrâ, s. 35-46.

168 Hıfzî, Şerhu Muhtâri'l-ikrâ, s. 46. 
Hıfzî, ferş-i hurûf konusunda Kur'ân'daki ferşe dair hususları Bakara sûresinden Enfâl sûresine, ${ }^{169}$ Enfâl'den Hûd'a, ${ }^{170}$ Hûd sûresinden Kehf sûresine, ${ }^{171}$ Kehf'den Haşr'e, ${ }^{172}$ Haşr sûresinden Furkân sûresine ${ }^{173}$ kadar olacak şekilde k1sım kısım verdikten sonra Kur'ân'ın sonundaki tekbir vecihleri ile eseri nihayete erdirmektedir. ${ }^{174}$

Hıfzî, konuların anlatımında Hamza ve Hişâm'ın vakıfları konusundaki gibi ${ }^{175}$ bazen Ali b. Süleyman el-Mansûrî'nin görüşlerini aktarır. Ancak aktarım esnasında Mansûrî’nin görüşünün hangi kaynakta geçtiğini zikretmez. Hifzî’nin eserini oluştururken istifade ettiği kaynaklar ise Şâtıbiyye, Dürre, Teysîr, ${ }^{176}$ Tahbîr, ${ }^{177}$ Kitâbü'l-Hâdî, Kitâbü'l-Kâfî, Kitâbü'l-Unvân, Kitâbü'l-Müstenîr ve Câmi 'u'lbeyân, ${ }^{178}$ Neşr, ${ }^{179}$ gibi kıraat ilminin temel eserleridir. Eserin ferağ kaydında hicrî 1197 senesinde tamamlandığına dair bilgi verilmiştir. ${ }^{180}$

\section{Sonuç}

Osmanlı öncesi tarik adı verilen kıraat eğitimiyle ilgili söz konusu yöntem ve ekoller, Osmanlı'da da devam ettirilmiştir. Ancak Osmanlı kıraat eğitiminde tariklerin uygulanmasında ve isimlendirilmelerinde birtakım değişikliklere gidilebilmiştir. Tariklerin uygulanmasındaki değişikliklere örnek verilecek olursa 'aşere ve takrib eğitiminde imamlarla birlikte râvileri ve tarikler de devreye girince, indirac tarikinin tatbikinde, Osmanlı'da daha önceleri metin ezberi söz konusu iken, zamanla kürrâseler devreye girmiş, her bir tarik ve meslek kendi usullerince birtakım kürrâse denilen defterler oluşturmuştur. Kıraat eğitimine verilen önemin azalması ve buna bağlı olarak talebe sayısındaki düşüş, talebelerdeki Arapça eğitimi hususundaki eksiklik ve ezberlerin ihmal edilmesi gibi birçok husus bu durumun oluşmasında sebep olarak gösterilebilir.

169 Hifzî, ŞerhuMuhtâri'l-ikrâ, s. 50.

170 Hifzî, Şerhu Muhtâri'l-ikrâ, s. 54-55.

171 Hifzî, Şerhu Muhtâri'l-ikrâ, s. 55-57.

172 Hifzî, ŞerhuMuhtâri'l-ikrâ, s. 57-61.

173 Hifzî, Şerhu Muhtâri'l-ikrâ, s. 61-63.

174 Hifzî, Şerhu Muhtâri'l-ikrâ, s. 63-79.

175 Hifzî, Şerhu Muhtâri'l-ikrâ, s. 39.

176 Hifzî, Şerhu Muhtâri'l-ikrâ, s. 3-4.

177 Hifzî, Şerhu Muhtâri'l-ikrâ, s. 5.

178 Hifzî, Şerhu Muhtâri'l-ikrâ, s. 8.

179 Hifzî, Şerhu Muhtâri'l-ikrâ, s. 40.

180 Hifzî, Şerhu Muhtâri'l-ikrâ, s. 70. 
Osmanlı'da tariklerin isimlendirilmesiyle ilgili değişikliklere gelince Osman11'daki İstanbul ve Misır tariklerinin isimlendirilmesi bu durumun örneklerindendir. Şöyle ki tasnif çeşitlerinden birinin de bölgelere izafe edilerek oluşturulduğu görülmektedir. Mesela Basra, Kûfe ve çevrelerinde yaygın bulunan Meşârike ekolüne (Teysir tarikine) Ahmet el-Mesyerî, İstanbul'da öncülük yaptığı için zamanla İslâmbol daha sonra İstanbul tariki denmeye başlanmıştır. Aslında İstanbul ve Irâkiyyûn tariki denildiğinde Meşârike ekolü (Teysir tariki) kastedilmektedir. Yine aynı şekilde İbnü'l-Cezerî’den Şâtıbiyye tarikine göre kıraat öğrenen öğrencileri Hicaz, Yemen, Mısır, Fas, Şam, Cezayir ve Tunus'ta bu tariki yaygınlaştırmışlardır. Bu ekole ravi ve kaynaklarına nispeten Meğâribe ekolü denmiştir. Şâtıbiyye tariki diye de bilinen adı geçen eğitim sistemi, Şehâze el-Yemenî’nin Mısır'da yaygınlaştırması sebebiyle zikri geçen bölgede Mısır tariki olarak anılmış, Mısır'dan Osmanlı'ya gelen Ali b. Süleyman el-Mansûrî vesilesiyle Osmanlı ilim camiasında da İstanbul tarikiyle beraber yaygınlık kazanmıştır.

Ayrıca temel eserlere göre tasnif türünde Zübdetü'l-'irfân'ın esas alınd1ğ Zübde tariki de Osmanlı'da öncesinden farklı olarak uygulanagelen bir tarik olmuştur.

Osmanlı'da tariklerle ilgili bu makalede zikredilmesi gereken bir diğer husus ise daha önce uygulanmış ancak zamanla kıraat eğitiminde unutulmuş Mahir ve Kabâkıbî tarikleridir. Bunlardan Kabâkıbî tariki Şemsüddîn Muhammed b. Halîl el-Halebî'nin, Mecma 'u's-Sürûr ve matla 'u'ş-şümûs ve'l-büdûr isimli on dört k1raate dair manzum eserini esas alan tariktir. Ancak incelemeler sonucunda Mahir tarikinin mahiyetine ulaş1lamamıştır.

Osmanlı'dan günümüze dek okutulagelen tarikler Misır ve İstanbul tarikleridir. Bahsi geçen tarikler arasında kullanılan kaynaklar farklı olmamakla birlikte bu kaynakların öncelik sıralaması ile temel veya yardımcı kaynak olarak kullanılması hususunda birtakım farlılıklar mevcuttur. Bunun yanında med mertebeleri ve usule dair vecihlerin siralamasında da iki tarik arasında bazı farklılıklar olabilmiştir.

Her iki tarik içinde de zamanla ruhsat ve azimet yönleriyle ilgili meslekler söz konusu olmuştur. Bunlar İstanbul tarikine mensup Îtilâf ve Sûfî meslekleri ile Misır tariki bünyesindeki Şeyh Atâullah ve Mutkin meslekleridir. Ancak meslek ehli insanlar kendi eğitim metodlarına bağlı kalmakla birlikte taassuba kapılmayıp âli isnada sahip olabilmek için diğer meslek veya tariklere mensup kişilerden de ders alabilmişlerdir.

Zikri geçen mesleklerden Îtilâf mesleğinin kurucusu Yûsuf Efendizâde diye meşhur Abdullah Hilmi'dir. Yûsuf Efendizâde eğitimde azimet metodunu tercih 
etmiştir. Bu mesleğin temel eseri ise Yûsuf Efendizâde'nin el-Îtilâffî vücûhi'l-ihtilâf isimli eseridir. Eser tayyibe tarikine göre yazıldı̆̆ için içinde rivayetlerle birlikte tarikler de söz konusudur. Ayrıca eser klasik kıraat kitaplarında olduğu gibi önce usûl sonrasında ferşe dair yazılmayıp, doğrudan Fatiha sûresiyle esere giriş yapılarak sadece ferşle alakalı konular ele alınmıştır. İstanbul tarikinin ikinci mesleği Sûfî mesleğinin kurucusu ise Kastamonulu Ahmed es-Sûfî'dir ve kendisi bu meslekte İstanbul tarikinin ruhsat yönünü tercih etmiştir. Kaynaklar hususunda bu mesleğin diğerlerinden farkı mesleğin kendisine ait temel kaynak kabul edilebilecek bir eserinin bulunmayıp, mesleğin icrasında kürrâse denilen vücûhât çözümlemelerinin olduğu defterlere müracaat edilmesidir.

Mısır tariki Mutkin mesleğini tesis eden Kettânizâde diye bilinen Muhammed b. Mustafa en-Na ‘îmî' dir. Na 'îmî, mensubu olduğu tarikin azimet yönünü tercih etmiştir. Mesleğin ismi Kettânizâde'nin eseri Mutkinü'r-rivâye'den gelir. Mesleğin temel kaynağı da zikri geçen eserdir. Müellif eserinin kıraatin bir nevi tahrirat kısmıyla ilgili olduğunu belirtir. Mısır tarikinin ikinci mesleği ise Atâullah mesleğidir. Atâullah en-Necîb b. el-Hüseyin'in kurucusu olduğu bu mesleğin temel kaynakları ise Güllü Hâfız diye de bilinen Ahmed Rüşdî'nin Mürşidü tt-talebe isimli eseri ile Ârif Hıfzî'nin Muhtâru'l-ikrâ'sıdır. Adı geçen meslek Misır tarikinin hali hazırda icra edilen tek mesleğidir ve bağlı bulunduğu tarikin ruhsat yönünü tercih eder. Yûsuf İmamzâde lakaplı Ahmed Rüşdî, kitabının yazımında tahrirata dair daha önce yazılmış üç eserden etkilendiğini ve eserini de bir nevi bu üç eserin bir araya getirilmiş hali olarak gördügünü dile getirir. Hıfzî’nin Muhtâ$r u$ 'l-ikrâ isimli eseri ise Mısır tarikine göre bazı meselelerin ele alındığı manzum bir eserdir. Bu eser üzerine aynı müellifin Muğni'l-kurrâ isimli şerhi bulunmaktadır. Bu eserin içeriğini ise kıraat sahasının temel eserlerinden Hırzü'l-emânî ve Dürre'ye dair ihtilaflar oluşturmaktadır. 


\section{Kaynakça}

Adıgüzel, Mehmet, "Kıraat İlminde Tarik-Senet Boyutu ve Konu İle İlgili Te'lif Edilen Eserler", Atatürk Üniv. Ilahiyat Fak. Dergisi, 16, 2001.

Akakuş, Recep, "Reîsülkurrâ", DİA, XXXIV İstanbul, 2007.

Akdemir, Mustafa Atilla, "Hamid b. Abdülfettâh el-Paluvî Hayatı, İlmi Şahsiyeti, Eserleri ve Zübdetü'l-'İrfân Adlı Eserinin Metodolojik Tanıtımı ve Tahkiki”, (Yayımlanmamış Doktora Tezi), Marmara Üniv. Sosyal Bilimler Enstitüsü, İstanbul, 1999.

, Kıraat İlmi Eğitim ve Öğretim Metodları, İstanbul, İFAV Yayınları, 2013.

, "Kıraat Eğitiminde Tarikler", Abdurrahman Gürses Anısına I. Kur'ân ve Kıraati Sempozyumu, Sakarya, Sakarya Üniversitesi Yayınları, 2000.

Akyüz, Abdullah, "Osmanlı Kıraat Âlimleri”, (Yayımlanmamış Yüksek Lisans Tezi), İstanbul Üniv. Sosyal Bilimler Enstitüsü, İstanbul, 2016.

Alemdar, Yusuf, "Osmanlı'da Dârülkurrâ Müessesesi ve Kıraat Eğitimi”, (Yayımlanmamış Doktora Tezi), Ankara Üniv. Sosyal Bilimler Enstitüsü, Ankara, 2003.

Ali el-Kārî, Ebü'l-Hasen Nûreddin b. Ali b. Sultan Muhammed, el-Minehü'l-fikriyye 'alâ metni'l-Cezerîyye, Kahire, Matbaatü'l-Meymeniyye, 1308.

Arslan, Durmuş, “Abdülhamid Rüştü (Görücü) Efendi (1860-1923) ve İcâzetnâmeleri”, Cumhuriyet Üniv. Ilahiyat Fak. Dergisi, 1, 2011.

Bennâ, Şihâbüddîn Ahmed b. Muhammed, İthâf-u fuzalâ 'i'l-beşer, thk. Şaban Muhammed İsmail, I, Beyrut, Alemü'l-Kütüb, t.y.

Bursal1, Mehmed Tâhir, Osmanlı Müellifleri, hzr. Ali Fikri Yavuz- İsmail Özen, İstanbul, Meral Yayınları, t.y.

Ebû Bekir Ahmed b. Muhammed, Şerhu Tayyibeti'n-neşr, Kahire, Dâru'sSahâbe li't-Türâs, 2005.

Gökdemir, Ahmet, Ali b. Süleyman el-Mansûrî ve Meşhur Mısır Tariki Kurrâları, (Yayımlanmamış Doktora Tezi), Yalova Üniv. Sosyal Bilimler Enstitüsü, Yalova, 2017.

, "Osmanlı Kur'ân Eğitim Merkezleri: Dârülkurrâlar ve Sibyan Mektepleri”, Edebali İslamiyat Dergisi, 1/2, 2017.

Hıfzî, Arif b. İbrahim, el-Mecmâ ' fi'l-kırâ'âti'l-erba 'a, Marmara Üniv. İlahiyat Fak. Ktp., Ali Üsküdarlı Blm., nr. 57. 
Blm., nr. 177.

, Muğni'l-kurrâ fî şerhi muhtâri'l-ikrâ, Beyazıt Ktp., Beyazıt

Hocazâde, Ahmed Hilmi, "Ravdatü'l-kurrâ", Strât-ı Müstakîm Mecmuası, $\mathrm{VI} / 148$.

Irmak, Mustafa, "Bir Belâgat Kitabı Olarak Mutavvel ve Osmanlı Medreselerinde Okunuş Biçimi Üzerine Bir Risâle", Marmara Üniv. İlahiyat Fak. Dergisi, 42, 2012.

İbnü'l-Cezerî, en-Neşr, II, Beyrut, Dârul Kütübi'l-İlmyye, t.y.

İbnü'l-Kabâkıbî, Şemsüddîn Muhammed b. Halîl el-Halebî, İzâhu'r-rumûz ve miftâhu'l-künûz, Süleymaniye Ktp., Kılıç Ali Paşa Blm., nr. 23; Fâzıl Ahmed Paşa Blm., nr. 19.

İbnü'l-Kabâkıbî, Mecma 'u 's-sürûr ve matla 'u'ş-şümûs ve'l-büdûr, Süleymaniye Ktp., Bağdatlı Vehbi Blm., nr. 31.

İslambulî, Mustafa b. Hasen, Mürşidü 't-talebe, Süleymaniye Ktp., Hac1 Selim Ağa Blm., nr. 29.

Karaçam, İsmâil, Kur'ân'ın Nüzûlü ve Kıraati, İstanbul, Nedve Yayınları, 1981.

Kastamonî, İsmail Hakkı, İcâzetnâme, Süleymaniye Ktp., Yazma Bağışlar Blm., nr. 2870.

Kılıç, Mustafa, "İmam-Hatip Ortaokul ve Liselerinde Kur'ân Eğitimi Üzerine Bir Araştırma”, Marmara Üniv. Illahiyat Fak. Dergisi, 47, 2014.

Mansûrî, Ali b. Süleyman, İcâzetnâme, Süleymaniye Ktp., Reşid Efendi Blm., nr. 24; İcâzetnâme, Muhammed b. Suûd Üniv. Ktp., nr. y.

Maşalı, Mehmet Emin, "Osmanlı Dönemi Tefsir Usûlü Çalışmaları”, Başlangıçtan Günümüze Türklerin Kur'ân Tefsirine Hizmetleri, (Tebliğler ve Müzakereler), İstanbul, y.y., 2011.

Müstakimzâde, Süleyman Sâdeddin, Tuhfe-i hattâtîn, İstanbul, y.y., 1928.

Na 'îmî, Muhammed b. Mustafa, Mutkınü 'r-rivâyefí ulûmi'l-kırâ'âti li'd-dirâye, Süleymaniye Ktp., Bağdatlı Vehbi Blm., nr. 21.

Blm., nr. 3405.

, Tehzîbü'l-tilâve fì 'ilmi 't-tecvîdi ve'l-kırâe, Milli Ktp., Yazmalar

Rûmî, Muhammed Emîn, Umdetü'l-hullân fî îzâhi Zübdetü'l-İrfân, İstanbul, Âsitâne, t.y. 
,Umdetü 'l-hullân fî̀izâhi Zübdetü'l-İrfân, İstanbul,y.y, 1270/1853. , Zühru'l-erîb fî îdâhi'l-cem 'i bi 't-takrîb, Süleymaniye Ktp., İbrâhim Efendi Blm., nr. 11.

Süreyya, Mehmed, Sicill-i Osmânî, İstanbul, Türk Tarih Vakfı Yurt Yayınları, 1996.

Sürûrî, Süleyman, İcâzetnâme, Süleymaniye Ktp., Galata Mevlevihânesi Blm., nr. 129.

Şeyhî, Mehmed Efendi, Vekāyiu'l-fuzalâ, nşr. Abdülkadir Özcan, III, İstanbul, Çağrı Yayınları, 1989.

Tanman, M. Baha, “Atâ Efendi Tekkesi”, DİA, IV, İstanbul, 1991.

Tobay, Ahmet, "Yusuf Efendizade Abdullah Hilmi ve Hadis Şerhçiliğindeki Yeri”, (Yayımlanmamış Doktora Tezi), Marmara Üniv. Sosyal Bilimler Enstitüsü, İstanbul, 1991.

Vada, Abdürrahim Cabir, Boğaziçi Konuşuyor ve Kanlıca Tarihçesi, İstanbul, Kitabevi, 2004.

Yılmaz, Ahmet, "Müstakimzâde Süleyman Sâdeddin”, DİA, XXXII, İstanbul, 2006.

Yûsuf Efendizâde, Abdullah Hilmi, el-Îtilâffì vücûhi'l-ihtilâf, Süleymaniye Ktp., M. Hilmi- H. Fehmi Blm., nr. 4-5; Özel Blm., nr. 537/2, vr. 17-92; Ömer Sindel Blm., nr. 53/2.

Yûsuf Efendizâde, İnâye, Süleymaniye Ktp., Nuruosmaniye Blm., nr. 1042.

, Mes'eletü âl'âne fì ilmi vücûhi'l-Kur'ân, Süleymaniye Ktp., Laleli B1m., nr. 22/3, vr. 97a-107a.

, Risâle fî beyâni merâtib-i med, Süleymaniye Ktp., Kasidecizâde Blm., nr. 15/2, vr. 173-180.

, Risâle fì beyâni merâtibi 'l-meddât, Süleymaniye Ktp., Mihrişah Sultan Blm., nr. 2/2, vr. 132-148.

, Risâle fî ecvibeti'l-mesâil mimmâ yetealleku bi vücûhi'l-Kur'ân, Süleymaniye Ktp., Fatih Blm., nr. 68/4, vr. 29a-39a.

, Risâle fì halli ba 'zl'l-işkâlât, Süleymaniye Ktp., İbrâhim Efendi Blm., nr. 66/2, vr. 27-54; Raşid Efendi Blm., nr. 1227/1.

, Risâle fî harf-i dâd'is-sahîha, Süleymaniye Ktp., Hamidiye Blm., nr. 1261/7, vr. 71-75. 
, Risâle fì reddi'l-kırâ'âti bi'ş-şevâz, Süleymaniye Ktp., Fatih Blm., nr. 68/2, vr. 11-22 ve nr. 5328/2, vr. 43b-57b; Laleli Blm., nr. 22/4, vr. 107118; İbrâhim Efendi Blm., nr. 28/12, vr. 69-81.

, Risâle fì tahkîki ba 'zı vücûhi'l-kırâ'âti fi'ş-Şâtıbîyye, Süleymaniye Ktp., Hac1 Selim Ağa Blm., nr. 4/2, vr. 87-9 ve nr. 5/5, vr. 360-399. nr. 2/3, vr. 149-161.

, Risâle fî vakf-i Hamza, Süleymaniye Ktp., Mihrişah Sultan Blm.,

Yûsuf İmamzâde, Ahmed er-Rüşdî, Mürşidü t-talebe ilâ îdâhi vücûhi b'adi âyâti'l-Kur'âniyye, Süleymaniye Ktp., Fatih Blm., nr. 71.

Yüksel, Ali Osman, “İbnü’l-Cezeri’nin Tayyibetü’n-Neşr’i ve Özellikleri”, Marmara Üniv. Illahiyat Fak. Dergisi, 7-10, 1989-1992. 
